\author{
UNIVERSIDADE DE SÃO PAULO \\ FACULDADE DE ODONTOLOGIA DE BAURU
}

SAMIRA SANDY FERREIRA STRELHOW

Analysis of marginal chipping of monolithic lithium disilicate crowns produced by four CAD-CAM systems

Análise do lascamento marginal de coroas monolíticas de dissilicato de lítio confeccionadas por quatro sistemas CAD/CAM 



\title{
Analysis of marginal chipping of monolithic lithium disilicate crowns produced by four CAD-CAM systems
}

\author{
Análise do lascamento marginal de coroas monolíticas de \\ dissilicato de lítio confeccionadas por quatro sistemas CAD/CAM
}

Dissertação constituída por artigo apresentada a Faculdade de Odontologia de Bauru da Universidade de São Paulo para obtenção do título de Mestre em Ciências no Programa de Ciências Odontológicas Aplicadas, na área de concentração Reabilitação Oral.

Orientador: Prof. Dr. Accácio Lins do Valle

BAURU 
Strelhow, Samira Sandy Ferreira

St83a Analysis of marginal chipping of monolithic lithium disilicate crowns produced by four CAD-CAM systems / Samira Sandy Ferreira Strelhow - Bauru, 2017.

84 p. : il. ; $30 \mathrm{~cm}$.

Dissertação (Mestrado) - Faculdade de Odontologia de Bauru. Universidade de São Paulo

Orientador: Prof. Dr. Accácio Lins do Valle

Autorizo, exclusivamente para fins acadêmicos e científicos, a reprodução total ou parcial desta dissertação por processos fotocopiadores e outros meios eletrônicos.

Assinatura: 
FOLHA DE APROVAÇÃO 



\section{DEDICATÓRIA}

À Deus, por me guiar, proteger e me amparar em todos os momentos. Sou grata por tudo que Ele fez e faz por mim, por me conceder força e sabedoria para que este sonho fosse concretizado. Obrigada Senhor por traçar meu caminho com tanto amor e carinho, sem o seu sustento não seria nada.

À minha Mãe, Eliete Ferreira, por ser meu porto seguro, minha amiga, minha rocha, por me incentivar a buscar meus objetivos e não medir esforços para que isso aconteça. Obrigada por fazer dos meus sonhos os seus! Agradeço imensamente a sua dedicação e mesmo com a distância seu amor chegou até mim em todos os momentos, mostrando o quão imensurável e poderoso é o seu amor. A senhora é meu exemplo de garra, honestidade e determinação. Esta e qualquer outra conquista que venho a ter é mérito nosso. Tudo que faço é pensando no melhor que posso te oferecer. Te amo!

À minha família, que me apoia e torce sempre para que meus desejos sejam concretizados. Vocês são meus maiores incentivadores mesmo nos momentos mais conturbados e me inspiram todos os dias a ser uma pessoa melhor. Obrigada a todos pelo amor, compreensão e por serem fonte de alegria e determinação.

Amo vocês! 



\section{AGRADECIMENTOS}

Em especial, ao Prof. Dr. Accácio Lins do Valle, meu orientador e professor, pelo qual tenho profunda admiração e respeito. Confesso que no momento em que nos conhecemos e o senhor disse que "orientar mulher pode ser um problema, mulher chora", fiquei assustada. O meu espanto logo deu espaço para a grande afeição que tenho pelo senhor. Admiro sua competência, generosidade, paciência, amizade e dedicação. Diante da ausência da minha família, posso dizer que o considero meu pai científico. Obrigada pelo incentivo, pelas oportunidades, por acreditar em mim e fazer parte do meu crescimento profissional. É uma honra ser sua orientada!

Ao nosso grupo de pesquisa: Hugo Alberto Vidotti e Gustavo Henrique Barbosa de Andrade que com grande generosidade me guiaram e incentivaram. Obrigada por tudo e contem sempre comigo!

À Faculdade de Odontologia de Bauru, Universidade de São Paulo, na

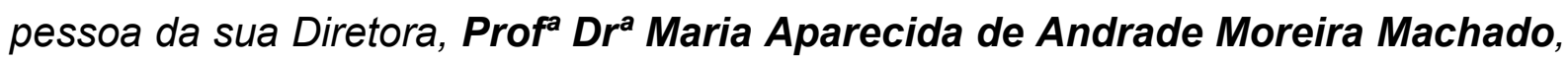
minha segunda casa. Os conhecimentos aqui adquiridos são infindáveis. Não há dúvidas que essa escola é um divisor de águas na minha formação. Sinto muito orgulho de ser filha desta escola.

Ao Departamento de Prótese da FOB-USP, representado pelo Prof. Dr. José Henrique Rubo, fazendo-se membro junto aos professores doutores: Paulo César Rodrigues Conti, Ana Lúcia Pompéia Fraga de Almeida, Carlos dos Reis Pereira de Araujo, Estevam Augusto Bonfante, Gerson Bonfante, Karin Hermana Neppelenbroek, Lucimar Falavinha Vieira, Pedro César Garcia de Oliveira, Renato de Freitas, Simone Soares, Vinícius Carvalho Porto e Wellington Cardoso Bonachela. A admiração e inspiração que tenho por todos é imensurável. Agradeço por compartilharem seus conhecimentos durante esses anos.

Ao Prof. Dr. José Henrique Rubo, a quem tenho profunda admiração e respeito. Obrigada pelos conhecimentos adquiridos durante o mestrado, por me dar a oportunidade de trabalhar com o senhor e acompanhar cada etapa desse estudo. 

Agradeço por ter me acolhido de braços abertos e tornar essa caminhada mais prazerosa. Generosidade, paciência e ética são sua marca registrada e um modelo a ser seguido.

Ao Prof. Dr. Luiz Fernando Pegoraro, exemplo de educador e o alicerce da pós-graduação em Reabilitação Oral. A generosidade, paciência e o amor com que se dedica às atividades acadêmicas é de uma nobreza sem igual. Obrigada pelos ensinamentos e por me inspirar sempre.

À secretária do Departamento de Prótese Déborah Andrea Riêra Blasca, por toda paciência e comprometimento. Aos funcionários: Cleide Vital Martins, Marcelo Henrique G. de Sousa, Valquíria F. Nogueira e Ziley Mara Calepso de Castro, pela atenção e solicitude. Em especial ao técnico de prótese Reivanildo $\boldsymbol{F}$. Viana pela delicadeza e disposição sempre.

À equipe de pós-graduação da FOB-USP, Cleusa Gonçalves Leite e Hebe Joselina de Freitas Pereira, pessoas excepcionais que desempenham papel fundamental para que as clínicas da pós-graduação aconteçam, por todo carinho e alegria com que me receberam. Às secretárias Ana Letícia Polombo Momesso, Fátima Cassador Carvalho e Leila Regina da Silva Yerga Sanchez.

Aos meus colegas de pós-graduação: llana Ramalho, Andréa Falcão, Thereza Pacheco, Verena Cunha, Patrick Alves, Oscar Marcillo, Vinícius Rizzo, Guilherme Moreira, Naila Machado, Fernanda Sampaio, Fernanda Furtado Piras, Fernanda Ferruzi, Leonardo Marques, Denise Gusmão, Vinicius Fardin, Camila Machado, Henrique Quevedo, Janaína Maciel, Ernesto Benalcázar, Ana Paula Chappuis, Leadiane Sandes, Jéssica Moreno, Cristiane Marques, Bárbara Margarido Brondino, Milena Steluti Marques, Letícia Fiedler, Laila Aguiar, Clara Fassoni Bonachela, Adolfo Coelho, Rodrigo Moreira, Nicole Freitas, Thais Fuzer, Luisa Guerrini por todo conhecimento compartilhado, pelo companheirismo e convívio harmonioso. 

À amiga Natália Almeida Bastos com quem compartilho todos os meus dias. Mesmo cursando a mesma faculdade na graduação, foi durante a pós-graduação que aprendemos a nos amar e respeitar. Tenho profunda admiração por você, seu caráter, respeito com o próximo, determinação e generosidade são qualidades exemplo para qualquer pessoa. Obrigada pelo convívio, por tornar essa fase mais leve, pelos conselhos, pelas alegrias e tristezas compartilhadas. Tenho certeza que Deus preparou nosso encontro com muito zelo, e é dessa forma que quero manter nossa amizade! Não poderia deixar de agradecer também sua família, Gianna Arpini Almeida Bastos e Lyrio Ferreira Bastos Netto. Tenho profundo carinho e respeito por vocês. Obrigada pela generosidade e por compartilhar tantos momentos felizes!

À amiga Brunna Mota Ferrairo. Não tenho palavras para descrever o quanto você foi e é importante na minha vida! Tenho certeza que Deus providenciou nosso encontro quando ambas precisávamos. Não preciso falar o tamanho da admiração e orgulho que tenho de você. Sua garra e perseverança me inspiram todos os dias. Sei que independente do que acontecer você sempre estará por perto para me ajudar e saiba que pode contar comigo sempre. Muito obrigada pela amizade sincera, pelas horas de estudo, pelos concelhos, conversas e alegria que me traz. Esse é só o começo de um longo caminho que vamos trilhar juntas! You are my person! Meu agradecimento também se estende a Rosangela Fidelis da Mota Ferrairo, que considero uma mãe postiça. Obrigada por me acolher tão bem, pelos conselhos, carinho e momentos tão felizes compartilhados. Hoje meu coração é metade capixaba e metade são paulino pela presença de vocês na minha vida.

À amiga Camila Perfeito por quem tenho profundo carinho. Você é uma pessoa sensacional, muito obrigada por todos os momentos de reflexão, trabalho, ajuda e compartilhar vários momentos prazerosos. Te desejo as melhores coisas que a vida pode oferecer porque você merece. Conte sempre comigo!

Às amigas Cindy Ruiz Garcia e Dyna Mara Ferreira por serem minhas companheiras nesta caminhada. Obrigada por todo incentivo, conversas sinceras e alegria. Os meus dias são mais leves com vocês! 



\section{Ao Departamento de Dentística, Endodontia e Materiais Odontológicos,}

representado pelo Prof. Dr. Rafael Francisco Lia Mondelli, pela receptividade com que sempre me trataram e pelo compartilhamento de conhecimento.

Ao Prof. Dr. Marco Antonio Hungaro Duarte, por ter aberto as portas do Laboratório de Endodontia, tornando essa pesquisa possível. Obrigada aos pósgraduandos do departamento Murilo Alcalde, Jussaro Duque e Bruno Martini Guimarães, pela disponibilidade e ajuda com os equipamentos.

À Profa Dra Ana Flávia Sanches Borges, meu muito obrigada pela oportunidade de trabalhar no laboratório do Departamento de Materiais Dentários e contribuir pelo desenvolvimento dessa pesquisa. A senhora me acolheu de braços abertos e não tenho palavras para expressar minha gratidão.

Às secretárias do Departamento de Materiais Odontológicos: Sandra Cléa Pirola Azuaga e Neide Leandro. Obrigada pelo carinho, disponibilidade e atenção.

Ao técnico de laboratório Alcides Urias da Costa, por sempre estar disposto a ajudar, mesmo quando atarefado ou durante as férias, nunca hesitou em fazer o possível e o impossível para que essa pesquisa fosse realizada. Muito obrigada pela generosidade e dedicação!

Ao Prof. Dr. Heitor Marques Honório, pela análise estatística e pelas contribuições no design desse trabalho. Muito obrigada pela sinceridade e delicadeza que trabalha.

À Prof. ${ }^{a}$ Dr. ${ }^{a}$ Stefânia Kano, por ser um exemplo do que é ser docente. A senhora não só despertou em mim a paixão pela Reabilitação Oral, mas também o desejo de seguir uma carreira acadêmica. Minha admiração pelo seu caráter, generosidade, delicadeza e ética é enorme e me inspiram todos os dias. 

Aos Profs. Drs. Luiz Gustavo Daroz, Anuar Xible, Murilo Auler e Salles, Glauco Rangel Zanetti e Marcelo Peçanha por compartilharem o conhecimento na área da Reabilitação Oral e terem me concedido a oportunidade de trabalhar com vocês dentro e fora da Universidade Federal do Espírito Santo.

Aos pacientes que pude acompanhar durante esta trajetória, pela compreensão e colaboração durante o aprendizado.

\section{À Conselho Nacional de Desenvolvimento Científico e Tecnológico} (CNPq) pela bolsa de Mestrado, auxílio indispensável para a realização deste trabalho.

À Fundação de Amparo à Pesquisa do Estado de São Paulo (FAPESP), pelo financiamento desta pesquisa - Processo 2013/10021-5.

Aos professores integrantes da banca examinadora, pela disponibilidade em analisar, avaliar e contribuir para aprimorar o presente trabalho.

Aos meus Padrinhos, Lúcia Inácio e Lúcio Inácio, exemplos de dedicação, honestidade, perseverança e fé. Obrigada pelas orações, incentivo e força!

Aos tios e tias de sangue e de coração. Muito obrigado por serem meu porto seguro e alicerce da família. Sem a dedicação, zelo, amor e acima de tudo, orações esse sonho não poderia ser realizado. Amo todos!

Aos meus primos e primas, pelo apoio e companheirismo mesmo à distância. É muito bom saber que sempre podemos contar uns com os outros. Vocês são fonte de felicidade e dedicação. A saudade é grande, mas quando estamos juntos tudo é recompensado. Amo muito vocês! 

Ao meu namorado e melhor amigo, Lucas Depoli de Figueiredo, por estar presente em todos os momentos importantes da minha vida, pelo incentivo incondicional, por me confortar nas horas certas, compreender minhas atribulações, por trilhar esse caminho ao meu lado e compartilhar o amor que torna meus dias mais felizes e completos. O seu apoio foi essencial para a realização dessa etapa tão importante. Te amo!

À Bernadete Depoli. Não poderia deixar de agradecer a pessoa que plantou a semente da pós-graduação em mim. Os seus conselhos foram e são fundamentais para mim. Muito obrigado pelo apoio e incentivo! Sua determinação, perseverança, profissionalismo, ética e dedicação são exemplos que quero seguir na carreira e na vida. Tenho profunda admiração pela sua história e pelo seu caráter. Muito obrigada!

Às minhas amigas Nayra de Souza, Nathália Dornelas e Mariana Domingos. Vocês me provam todos os dias que verdadeiras amizades continuam crescendo mesmo a longas distâncias. Nossa amizade começou na graduação e com o passar dos anos só intensificou. Nós realmente sabemos que podemos contar uma com as outras em qualquer momento. Torço pelo sucesso de vocês, tanto quanto torço pelo meu. Obrigada por se fazerem sempre presentes de alguma forma. Amo vocês!

Aos amigos e amigas Bruna Cortes, Gabriela Freitas, Andréia Cristina, Joyce Andrade, Maynara Nascimento, Rayane Locatelli, Mirella Santos, Núbia de Castro, Karol Ayres, Lauro Sá e Renato Henrique. Amizades de longas datas que a distância só fortaleceu. Obrigada pelas doses diárias de alegria!

A todos que direta ou indiretamente torceram por mim, meu muito obrigada! 

"Aquele que tem uma profissão tem um bem; aquele que tem uma vocação tem um cargo de proveito e honra. " 

ABSTRACT 



\section{ABSTRACT \\ Analysis of marginal chipping of monolithic lithium disilicate crowns produced by four CAD-CAM systems}

Statement of the problem. The marginal integrity of monolithic crowns is an essential factor for longevity. Due to the wide application of CAD/CAM systems, evaluation of production accuracy is of great clinical interest.

Purpose. Evaluating the marginal chipping of monolithic lithium disilicate crowns produced by four different CAD-CAM systems.

Material and methods. Four CAD-CAM systems were selected: Ceramill (Ceramill Motion 2), Cerec (Cerec inLab MC XL), EDG (CAM5-S1 SmartDent) and Zirkonzahn (M5 Heavy). An artificial lower first molar was prepared for a full crown, duplicated in plaster, scanned and a crown was designed following standardized parameters. Ten lithium disilicate crowns (IPS e.max CAD) per group were milled. Images were obtained using a scanning stereomicroscope Stemi 2000-C (Zeiss), overlapped (Adobe Photoshop CS6 software) and measurents of the marginal perimeter and chipping area were performed (ImageJ software). To evaluate the degree of marginal chipping, the Chipping Factor (CF) of each crown was calculated and the data were subjected to Kruskal-Wallis One-way test followed by Dunn's method $(p<0.05)$.

Results. Based on SD and absolute mean values, the CF of Ceramill $(14,5 \pm 8,3)$ and Cerec $(13,4 \pm 9,4)$ groups was statistically higher than EDG $(3,4 \pm 1,2)$ and Zirkonzahn $(2,8 \pm 1,3)$.

Conclusion. The data demonstrated the influence of selected parameters during the design, parameters settings and manufacturing tools of CAD/CAM systems on the marginal integrity of monolithic crowns.

Key words: CAD/CAM. Dental Crowns. Dental Marginal Adaptation. Ceramics. 




\section{RESUMO}

\section{Análise do lascamento marginal de coroas monolíticas de dissilicato de lítio confeccionadas por quatro sistemas CAD/CAM}

Afirmação do problema. A integridade marginal de coroas monolíticas é um fator essencial para sua longevidade. Devido a ampla aplicação dos sistemas CAD-CAM disponíveis, a avaliação da precisão de sua produção é de grande interesse clínico.

Finalidade. Avaliação do lascamento marginal de coroas monolíticas de dissilicato de lítio produzidas por quatro sistemas CAD-CAM diferentes.

Material e métodos. Foram selecionados quatro sitemas CAD-CAM: Ceramill (Ceramill Motion 2), Cerec (Cerec inLab MC XL), EDG (CAM5-S1 SmartDent) e Zirkonzahn (M5 Heavy). Um primeiro molar inferior artificial foi preparado para coroa total, duplicado em gesso, digitalizado e a coroa foi projetada seguindo parâmetros padronizados. Dez coroas de dissilicato de lítio (IPS e.max CAD) foram fresadas por grupo. Para cada grupo o sistema foi utilizado em sua totalidade: scanner, software do design e unidade de fresagem. Imagens foram obtidas usando $o$ estereomicroscópio Stemi 2000-C (Zeiss), sobrepostas (programa Adobe Photoshop CS6) e medidas do perímetro marginal e área de lascamento foram realizadas (programa ImageJ). Para avaliar o grau de lascamento da margem, o Fator de Lascamento $(F L)$ de cada coroa foi calculado e os dados foram submetidos ao teste de Kruskal-Wallis, seguido pelo método de Dunn $(p<0,05)$.

Resultados. Com base nos valores médios absolutos e DP, o FL dos grupos Ceramill $(14,5 \pm 8,3)$ e Cerec $(13,4 \pm 9,4)$ foram estatisticamente maiores do que os grupos EDG $(3,4 \pm 1,2)$ e Zirkonzahn $(2,8 \pm 1,3)$.

Conclusão. Os dados demonstraram a influência dos parâmetros selecionados durante o design, das configurações e ferramentas de confecção dos sistemas CAD / CAM sobre a integridade marginal das coroas monolíticas.

Palavras chave: CAD/CAM. Coroas dental. Adaptação Marginal Dentária. Cerâmica. 



\section{LIST OF ILLUSTRATIONS}

Figure 1 - Prepared tooth positioned in a mannequin 45

Figure 2 - Master die 46

Figure 3 - Lithium disilicate glass-ceramic crowns. 47

Figure 4 - Stereomicroscope Stemi 2000-C 48

Figure 5 - Bases of polyvinyl siloxane

Figure 6 - Crowns positioned in base 50

Figure 7 - Image overlapping on Adobe Photoshop CS6 software. 51

Figure 8 - Measures of ImageJ software 52

Figure 9 - Example of perfect margin 53

Figure 10 - Example of marginal chipping 54

Figure 11 - Chipping Factor (CF) analysis 55 



\section{LIST OF TABLES}

Table 1 - Mean CF and standard deviation of CAD/CAM systems....................56 



\section{TABLE OF CONTENTS}

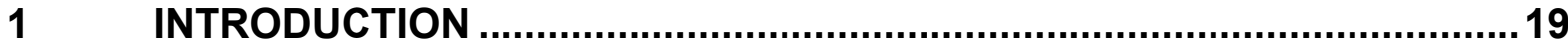

2 ARTICLE

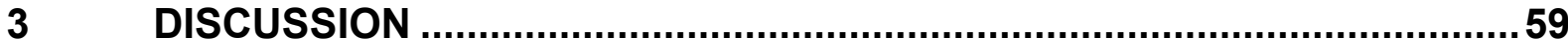

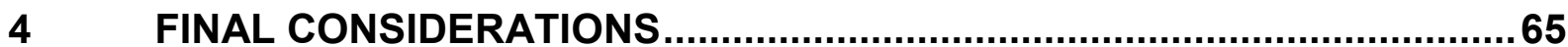

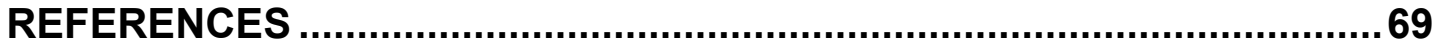

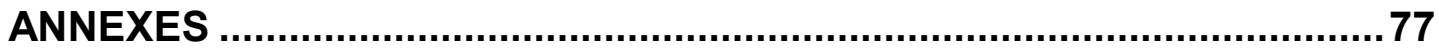



1 INTRODUCTION 



\section{INTRODUCTION}

Dental ceramics have been the mainstay of esthetic dentistry for decades, since they present satisfactory mechanical properties such as flexural strength, fracture toughness, thermal and electrical conductivity, great optical properties, high biocompatibility and reduced plaque accumulation. ${ }^{1-4}$ These characteristics are determined by the ceramic microstructure and consequently are subject to changes. ${ }^{3}$ The increase in the demand for aesthetic procedures in anterior and posterior regions has directly influenced the improvement of the optical and mechanical properties of dental ceramics.

Although ceramic materials demonstrate desirable properties, cohesive failures in veneer ceramic were reported as the most common complication. For this reason, monolithic restorations were introduced in recent years with the purpose of reducing the failures on veneer layer. ${ }^{5-7}$ Because of lithium disilicate excellent chemical durability, height flexural strength, high fracture load and improved translucency, it has become widely used for veneers, inlays, onlays, single crowns and multiple unit bridges. ${ }^{8-10}$

Monolithic lithium disilicate ceramic restorations have a cumulative survival rate of $100 \%$ after 5 years and $87,9 \%$ after 10 years showing similar survival rate of conventional metal-ceramic crowns. ${ }^{8}$ The longevity is influenced and dependent of many factors: tooth preparation characteristics, crown shape and thickness, elastics modulus of the restoration material, material selection, cement thickness, quality of laboratory processing and marginal and internal fit. ${ }^{11-13}$ Regardless of improvements in monolithic materials, complications can still affect the survival rates. ${ }^{8,14-15}$

Among these complications, the marginal and internal accuracy has been considered as a crucial factor for the success and survival of all-ceramic crowns. Deficiencies of marginal fit in the restoration may lead to the luting resin to be exposed to the oral environment, which would favor the material natural dissolution and leave the region more susceptible to bacterial infiltration, altering the composition of the subgingival microflora. ${ }^{16-18}$ This would result in marginal microleakage, which may increase susceptibility to plaque retention, marginal discoloration, dentin sensitivity, secondary caries, irritates the vital pulp and beginning of periodontal disease. In 
addition, the tooth cannot support properly restorations poorly adapted, inducing complete failure of ceramic restorations and affecting the restoration longevity. Therefore, marginal and internal accuracy are related to marginal integrity, and are considered key factors for the clinical quality of ceramic restorations. ${ }^{11,}$ 16-23

The method of laboratorial processing is also influenced by demand and receives constantly modifications. Although conventional dental ceramic manufacture presents an established high quality of production, the laboratory steps are still laborious and experience-dependent. ${ }^{24-29}$ Since ceramic materials are technically sensitive, new advanced processing technologies and automated systems have been introduced to improve their manufacture. The CAD/CAM (computer-aided design/computer-aided manufacturing) systems have a fundamental participation at this perspective. ${ }^{30}$ It allows restorations of high strength polycrystalline ceramics blocks to be fabricated ${ }^{31-34}$ and make possible restorations with optimal esthetic and functional outcomes to be made. ${ }^{11,35}$

CAD/CAM systems should ensure the ability to produce prosthetic restorations (1) with improved fit, (2) with adequate strength, (3) to decrease labor, (4) to enhance quality control, (5) with cost effectiveness and (6) that meets optical properties compared to conventional manufacturing processes using pressing or casting techniques. In addition to facilitate the process, making them faster and more accurate. ${ }^{24,36-37}$

Scanning process may undermine the precision, especially when an intra-oral scanner is used. However, companies have invested heavily in improving this technology to minimize errors. ${ }^{38}$ After scanning, the design setting of the restoration is essential. During this stage, it is possible to control parameters and modify the restoration morphology, considering the limits based on the mechanical properties of the selected material. Marginal gap, cement space, emergence profile, proximal contact strength, occlusal offset and marginal thickness are some of the adjustable parameters and variations will influence the quality of the final product. The last phase consists in the milling operation and it has a potential for generation of machining induced flaws. It could reduce the accuracy of restorations and consequently affect marginal adaptation and internal fit. ${ }^{39}$

The accuracy of the CAD/CAM system is paramount to control, improve, and maintain the quality of the product delivered. The success of the restoration is directly related to the clinical standards of strength, biocompatibility, marginal adaptation and 
color stability. ${ }^{12,40}$ However, the main challenge faced by the use of a CAD/CAM system is the marginal adaptation and the internal fit of restorations. As already mentioned, this problem has been identified as a vulnerable point of the system due the association with wear of the luting resin which may lead to wash-out and material collapse. The poor adaptation leads to a higher luting space resulting in dissolution of the luting resin, polymerization shrinkage, contraction gaps and leakage. ${ }^{41,42}$ Furthermore, it may complicate prosthesis cementation and final adjustment.

For this reason, margin quality has been described as an essential aspect considering the longevity of ceramic restorations manufactured by CAD/CAM. ${ }^{19-23}$ Marginal chipping, even small ones, may lead to biologic and mechanical complications, since marginal weaknesses can become stress concentration sites resulting in cracks, besides causing marginal gaps and disadjustments. ${ }^{41-43}$

Considering all these factors, the importance of properly understanding marginal chipping is demonstrated. However, there are few researches about this subject on the literature. Previous studies investigated the marginal integrity of ceramic crowns produced by CEREC CAD/CAM system. The results indicated increase of marginal chipping with acute bevel finishing lines showing that brittleness of a material increases the chipping factor. ${ }^{44}$ Another research evaluated the effect on the marginal integrity of copings using different CAD/CAM systems and different finishing lines. They found different amount of marginal chipping related with the CAD/CAM systems and with finishing lines. ${ }^{45}$

It is uncertain what factors are related to chipping of marginal region and their consequences. Therefore, the purpose of this in vitro study was to investigate the degree of marginal chipping of lithium disilicate crowns manufactured with four different CAD/CAM systems and the accuracy of their production. The null hypothesis is that there are no differences in the marginal chipping of the restorations among the systems. 

2 ARTICLE 



\section{ARTICLE}

The article presented in this Dissertation was written according to The Journal of Prosthetic Dentistry instructions and guidelines for article submission (Annex A). 


\section{ANALYSIS OF MARGINAL CHIPPING OF MONOLITHIC LITHIUM DISILICATE CROWNS PRODUCED BY FOUR CAD-CAM SYSTEMS}

\section{ABSTRACT}

Statement of the problem. The marginal integrity of monolithic crowns is essential factor for their longevity. Due the wide application of CAD/CAM systems, evaluation of the accuracy of its production is of great clinical interest.

Purpose. Evaluating of marginal chipping of monolithic lithium disilicate crowns produced by four different CAD-CAM systems.

Material and methods. Four CAD-CAM systems were selected: Ceramill (Ceramill Motion 2), Cerec (Cerec inLab MC XL), EDG (CAM5-S1 SmartDent) and Zirkonzahn (M5 Heavy). An artificial lower first molar was prepared for a full crown, duplicated in plaster, scanned and the crown was designed following standardized parameters. Ten lithium disilicate crowns (IPS e.max CAD) per group were milled. For each group the complete system was used: scanner, design software and milling unit. Images were obtained using a scanning stereomicroscope Stemi 2000-C (Zeiss), overlapped (Adobe Photoshop CS6 software) and measures of the marginal perimeter and chipping area were performed (ImageJ software). To evaluate the degree of marginal chipping, the Chipping Factor $(\mathrm{CF})$ of each crown was calculated and the data were subjected to Kruskal-Wallis One-way test followed by Dunn's method $(\mathrm{p}<0.05)$.

Results. Based on SD and absolute mean values, the CF of the Ceramill $(14,5 \pm 8,3)$ and Cerec $(13,4 \pm 9,4)$ groups were statistically higher than EDG $(3,4 \pm 1,2)$ and Zirkonzahn $(2,8$ $\pm 1,3)$.

Conclusion. The data demonstrated the influence of selected parameters during the design, parameters and manufacturing tools of $\mathrm{CAD} / \mathrm{CAM}$ systems on the marginal integrity of monolithic crowns. 


\section{INTRODUCTION}

Monolithic all-ceramic crowns have been widely used, since they present satisfactory mechanical properties, minimizing the presence of residual stress and cohesive failures in veneer ceramic. ${ }^{1-4}$ The high flexural strength, improved esthetics and possibility of using in anterior and posterior regions has become the lithium disilicate an excellent material option for monolithic dental crowns..$^{5-7}$

Monolithic lithium disilicate ceramic restorations have a cumulative survival rate of $100 \%$ after 5 years and $87,9 \%$ after 10 years showing, similar survival rate of conventional metalceramic. ${ }^{5}$ The prosthesis longevity is influenced and dependent of many factors, such as tooth preparation characteristics, crown shape and thickness, cement thickness, quality laboratory processing and marginal and internal fit. ${ }^{8-10}$ Regardless of all improvements in monolithic materials, complications can still affect the survival rates. ${ }^{5,11,12}$

Among the complications, the marginal and internal accuracy has been considered a crucial factor for success and survival of all-ceramic crowns. Deficiencies of marginal fit in the restoration may lead the luting resin exposed to the oral environment, which would favor the material natural dissolution and leave the region more susceptible to bacterial infiltration. ${ }^{13-15}$ This would result in marginal microleakages, which may increase susceptibility to plaque retention, marginal discoloration, secondary caries, irritates the vital pulp and beginning of periodontal disease. In addition, the tooth cannot support properly restorations poorly adapted, inducing complete failure of ceramic restorations and affecting the restoration longevity. ${ }^{8,13-20}$ The method of laboratorial processing is also influenced by demand and receives constantly modifications. The CAD/CAM (computer-aided design/computer-aided manufacturing) systems allows restorations of high strength polycrystalline ceramics blocks to be fabricated and make possible restorations with optimal esthetic and functional outcomes. ${ }^{21-24}$ However, the abrasive machining processes used by $\mathrm{CAD} / \mathrm{CAM}$ systems induce surface damages, which 
could reduce the accuracy of restorations and consequently affect marginal adaptation and internal fit. ${ }^{25}$ This, can result in serious implications related to integrity of monolithic lithium disilicate ceramic restorations.

Considering all of these factors, margin quality has been described as an essential aspect regarding the longevity of ceramic restorations manufactured by CAD/CAM systems. ${ }^{16-20}$ The marginal chipping, even the small ones, may lead to biologic and mechanical complications, since marginal weakness can become a stress concentration site, resulting in cracks, causing marginal gaps, disadjustments and any other problems arising from this. ${ }^{26-28}$ Previous research indicates the relation between the amount of marginal chipping with CAD/CAM systems and tooth preparation design. ${ }^{29,30}$ Despite the importance of properly understanding marginal chipping, there are few researches about this subject on the literature. Since these questions are already unstudied and it is remain uncertain, the purpose of this in vitro study was to investigate the degree of marginal chipping of lithium disilicate crowns manufactured with four different CAD/CAM systems and the accuracy of their production. The null hypothesis is that there are no differences in the marginal chipping of the restorations among the systems. 


\section{MATERIALS AND METHODS}

To determine the marginal integrity of the crowns through the degree of marginal chipping, forty lithium disilicate crowns produced by four CAD/CAM systems were obtained and analysed with a stereomicroscope.

\section{Tooth preparation and cast fabrication}

An artificial lower first molar positioned in a mannequin was prepared for a complete crown. The preparation comprised a $2.0 \mathrm{~mm}$ occlusal reduction, $1.5 \mathrm{~mm}$ axial reduction and a $1.2 \mathrm{~mm}$ shoulder finish line with rounded internal angles (Fig. 1).

An impression was taken using the double impression technique with polyvinyl siloxane material (Express; 3M ESPE, St Paul, USA). A plaster model was made with type IV special CAD/CAM stone (CAM-base; Dentona AG, Dortmund, Germany) (Fig. 2), scanned and the crown design was produced according to standardized parameters. For each group, the complete system was used: scanner, design software and milling unit.

\section{Standardized parameters}

In each CAD-CAM system the same parameters where selected and stablished according to the ceramic manufacturer's indication.

For the evaluation of marginal integrity, the following parameters are highlighted as the most capable of influencing the outcome:

- Margin Thickness: allows to increase the material amount in restoration margins. It prevents chipping of the porcelain during the milling process. Set up to $120 \mu \mathrm{m}$.

- Margin Ramp Width: allows to determine the length of the area with which the restoration rises from the preparation margin. Set up to $50 \mu \mathrm{m}$. 
- Margin Ramp Angle: allows to define the angle at which the restoration rises from the margin. Set up to $60^{\circ}$.

\section{Crowns fabrication}

Ten crowns per group were milled from lithium disilicate glass-ceramic blocks (IPS e.max CAD; Ivoclar-Vivadent, Amherst, NY) (Fig. 3). As standard, a wax-up model was used to determine the occlusal anatomy.

Four CAD-CAM systems were selected and the groups were named:

1. CERAMILL - Ceramill Motion 2 (Amann Girrbach AG, Koblach, Austria)

2. CEREC - Cerec inLab MC XL (Sirona Dental Systems GmbH, Bensheim, Germany)

3. EDG - SmartDent CAM5-S1 (EDG Equipamentos e Controles Ltda; São Carlos, Brazil)

4. ZIRKONZAHN - Milling Unit M5 Heavy (Zirkonzahn, South Tyrol, Austria)

After milling, crowns were sintered and glazed according to the manufacturer's instructions.

\section{Image Acquisition}

The marginal perimeter and integrity were examined using a scanning stereomicroscope Stemi 2000-C (Zeiss, Oberkochen, Alemanha; magnification: 0,8x-1,6x) connect to a computer (Fig.

4). The images were reproduced by assistance of AxionVision 4.9.1 imaging software.

Images standardization was ensured dividing the edge of the crown in 8 sections:

1. B (buccal)

2. BM (buccal-mesial)

3. BD (buccal-distal)

4. $\quad \mathrm{M}($ mesial)

5. D (distal)

6. L (lingual) 


\section{LM (lingual-mesial) \\ 8. LD (lingual-distal)}

This segmentation allowed proper observation with adequate focus in all the intended extension, facilitating the subsequent analysis, and ensuring that the entire perimeter was considered.

To enable the standardized positioning of the crown for the analysis, 8 bases were manufactured of polyvinyl siloxane (Express; 3M ESPE, St Paul, USA) (Fig. 5) dividing the sections of interest and named according to sessions (Fig. 6).

\section{Marginal Chipping Analysis}

The images were imported to Adobe Photoshop CS6 software which allowed the recognition of the chipping areas.

An ideal selected image, without marginal chipping, of each section was considered the baseline for overlapping the other imagens of the same section and group. This overlapping ensures the observation of the chipping area and, consequently, the perimeter for analysis (Fig. 7). After overlapping, the images obtained were imported to ImageJ software providing the perimeter measurements for each section by a single examiner and, thus calculated (Fig. 8).

An ideal margin was defined by the absence of interruption of continuity (Fig. 9), while the marginal chipping was defined as the interruption of this continuity (Fig. 10). Based on this principle, the margin of the selected region was initially outlined in all its length, disregarding eventual launches, characterizing the perimeter measure $(\mathrm{P})$. If there was marginal chipping, its extent was measured (L).

To find the degree of marginal chipping, the Chipping Factor (CF) of each crown was calculated. The equation was applied by region. The mean $\mathrm{CF}$ of each region was considered the total CF for each crown. 
The following equation was used to calculate CF. ${ }^{29}$

$\mathrm{CF}=[\mathrm{L} / \mathrm{P}] \times 100$

The benefit of this approach is to ensure a better quality of observation of the entire margin of the crown, allowing to measure chipping with greater accuracy.

\section{Statistical analysis}

The chipping values were imported into Statistica software (Statsoft ${ }^{\circ}$, Tulsa, Ok, USA). The means and standard deviation of the eight section were analyzed for each of 4 groups. KruskalWallis One-way analysis test was used to find any difference of the CF among the groups and the data were submitted to the Dunn's method to multiple comparisons between-group, at a statistically significant differences at $\mathrm{p}<0.001$. 


\section{RESULTS}

The means and standard deviation (SD) for chipping factor (CF) of each CAD-CAM system were obtained from Kruskal-Wallis one-way analysis of variance on ranks, at a significance level of $5 \%$ and were summarized in Table 1 . The Ceramill $(14,5 \pm 8,3)$ and Cerec $(13,4 \pm$ $9,4)$ groups showed higher values than $\operatorname{EDG}(3,4 \pm 1,2)$ and Zirkonzahn $(2,8 \pm 1,3)$ groups, demonstrating a heterogeneous distribution. This inconsistency in distribution could be related to inaccuracy of monolithic lithium disilicate crowns $(\mathrm{p}<0,001)$.

Pairwise multiple comparison procedures (Dunn's Method) was used to compare discrepancies among groups and indicated significant differences among them. The results obtained are shown in Graphic 1.

Data from this graphic demonstrate the differences between Ceramill and EDG, Ceramill and Zirkonzahn, Cerec and EDG and Cerec and Zirkonzahn. On the other hand, there was no disparities between Ceramill and Cerec and EDG and Zirkonzahn. The results indicate variations in the median values distribution among the treatment groups, highlights a statistically significant difference $(\mathrm{p}<0,05)$.

Overall, these results suggest the presence of differences in manufacturing process among the CAD-CAM systems. Zirkonzahn group showed a more uniform distribution of marginal chipping and higher accuracy in crown fabrication followed by, EDG, Cerec and Ceramill. Therefore, the null hypothesis was rejected. 


\section{DISCUSSION}

Marginal adaptation, internal fit and the quality of laboratory process are considered the essential factors for the longevity of all-ceramic crowns. ${ }^{8-10}$ The marginal integrity when presents discrepancies or gaps, it will directly influence the marginal adaptation and might result in higher susceptibility to secondary caries, plaque retention, marginal discoloration and also prevent the final adjustment. ${ }^{13-20}$

In this in vitro study, the marginal integrity of monolithic lithium disilicate (IPS e.max CAD) crowns manufactured by four different CAD/CAM systems was evaluated by quantitative image analysis, in order to determine if there is a difference in this characteristic among manufacturing systems.

The index used to determine the marginal integrity was chipping factor $(\mathrm{CF})$. The results showed an increase of the CF in CEREC (13,35\%) and Ceramill (11,84\%) groups. On the other hand, the EDG (3,02\%) and Zirkonzahn (2,33\%) groups presented lower rate of the CF. Multiple comparison analyses presented statistically significant differences between the groups with high and low $\mathrm{CF}(\mathrm{p}<0,05)$.

The data obtained in CEREC and Ceramill groups are opposite to a previous study using copings, which present lower values of $\mathrm{CF}^{30}$ Direct comparison can be realized in CEREC group with $0^{\circ}$ bevel angle copings, where the mean CF was $2,8 \%$ compared with $13,35 \%$ found by this study. It is important to emphasize that the difference of design between copings and crowns may affect the results, since the CAD-CAM manufacturing process produce in copings a collar at the margins, which function as a support while the crowns are milled until final shape, increasing the possibility of marginal chipping. ${ }^{30}$ The previous study correlated the machinability of glass ceramic materials through the chipping factor and brittleness calculation by single CAD/CAM system. They used the CEREC system to mill lithium disilicate crowns finding $69.8 \%$ of marginal chipping, which 
was significantly greater than present study. Moreover, their results showed a perfect positive correlation between brittleness and CF, however, in this study only one glass ceramic was used, which standardized the samples. ${ }^{29}$ Another finding that emerge from the analysis is related to occurrence of difference in milling process of CAD/CAM systems which have different effects on the quality of the restorations.

The machinability of CAD/CAM systems may be the reason of the variations between groups. The machining processes create, through the milling burs contact, trace lines inducing few microscopic defects. Although microscopic, these defects promote surface damages that enables stress concentration increasing the susceptibility for crack initiation that, in turn, may increase with mastication. Therefore, microscopic flaws lead to small cracks, which can grow and result in larger cracks reducing strength and fatigue life or even causing catastrophic failure. $^{31-34}$

Other relevant issues that requires attention apply to the marginal thickness and marginal ramp width. According to the manufacturing companies, the amount of ceramic present at the margin of the restoration can vary without affecting the adaptation. However, a smaller thickness of material in margin may turn the margin restoration more susceptible to damage derived from milling process. The margin ramp width establishes the length of the area that the restoration rises from the dental preparation. Minimally invasive preparation can reduce the width of finish lines producing restorations with low thickness, which may hamper the marginal integrity. Furthermore, the burs diameter of CAD/CAM systems cannot be compatible with the thickness restoration and provide damages in milling resulting in margins defects. ${ }^{35}$

The extension of damage can be influenced by size of the bur, wear of cutting tool, number of axes, applied load and grinding speed. ${ }^{7,20,36,37}$ The size of the burs limits the accuracy of the milling process, since the crowns fine details can be incompatible with them. ${ }^{37}$ In this study, 
the burs indicated by each system were used considering the fabrication of a monolithic lithium disilicate crown.

Regarding to number of axes, all systems presents 5 axes that enable linear movement and rotations in three spatial directions $\mathrm{X}, \mathrm{Y}, \mathrm{Z}$. The ceramic block rotates around $\mathrm{X}$ axes and milling spindle rotation around $\mathrm{Y}$ axes. These freedom of rotation allows higher accuracy of the milled restorations. ${ }^{20,27}$

Another factor that could influence the final aspect of the margin is the time consuming for the milling operation. The shorter is the process time, the greater is the production rate, although the probability for inaccuracy and marginal chipping will be higher, resulting in reduced success rate. ${ }^{27,37}$ In present research, the time spent for manufacturing was $14 \mathrm{~min}$ (CEREC), $30 \mathrm{~min}$ (Ceramill), $30 \mathrm{~min}$ (EDG) and $40 \mathrm{~min}$ (Zirkonzahn). The CAD/CAM systems have the option of changing the milling time, speeding up or not the process. Often, this decision is determined by the operator. Further studies, that considers these variables, need to be undertaken.

The CF method analysis was initially described by Tsitrou et al. ${ }^{29}$ however in the present study, modifications was realized for allowing a detailed observation of crown margins. The equation was also adapted to guarantee that the chippings were measured and belonged to the right perimeter. Therefore, the perimeter extent was unique for each section. Furthermore, the setting of measures were performed after overlaying the images allowing all of the chipping areas to be involved, opposed to what happens in this previous study.

The correlation between the amount of degree of marginal chipping and longevity of allceramic restorations remain unknown. Consequently, we cannot be assertive of what chipping percentage is necessary to affect the survival rates. ${ }^{30}$ However, previous researches have suggested the possibility of structural surface flaws acting as stress concentration sites. The stress magnitude will depend on the severity of the surface defect, thus the greater the surface 
defect, the higher the stress concentration. Consequently, the potential of flaws to become crack initiation sites, affecting survival probability. ${ }^{31}$ Furthermore, flaws may assume the form of micro cracks and are unlikely to allow visual detection, due their sub-millimeter scale. ${ }^{32}$

Therefore, understand the damages produced by CAD/CAM milling, it is important to highlight the marginal integrity role in success of ceramic restorations. It is necessary greater emphasis in parameters selections during design process, materials choice and milling time process, given the impact of marginal integrity role in success rates of all-ceramic restorations. Future investigations could clarify questions about the theme. 


\section{CONCLUSIONS}

The present study was designed to determine the degree of marginal chipping of lithium disilicate crowns manufactured by four different CAD/CAM systems and evaluate the accuracy of its production.

Within the limitations of this in vitro study and the lack of detailed information about some $\mathrm{CAD} / \mathrm{CAM}$ systems, it was concluded that the chipping factor of monolithic lithium disilicate crowns exhibit statistical differences among the test groups $(p<0.001)$. Zirkonzahn showed the uniform distribution and the lowest percentage of chipping in marginal region. The current data highlight the influence of the restorations design, settings and tools of CAD/CAM systems have in final integrity of the prosthesis margin.

Furthermore, the clinical importance of chipping margin remains unclear, which suggests future in vivo studies to evaluate the marginal chipping and clinical performance of monolithic crowns made from different CAD-CAM systems. 


\section{REFERENCES}

1. Schultheis S, Strub JR, Gerds TA, Guess PC. Monolithic and bi-layer CAD/CAM lithium-disilicate versus metal-ceramic fixed dental prostheses: Comparison of fracture loads and failure modes after fatigue. Clinical Oral Investigations. 2013;17:1407-1413.

2. Seydler B, Rues S, Müller D, Schmitter M. In vitro fracture load of monolithic lithium disilicate ceramic molar crowns with different wall thicknesses. Clinical Oral Investigations. 2014;18:1165-1171.

3. Nordahl N, Steyern PVV, Larsson C. Fracture strength of ceramic monolithic crown systems of different thickness. Journal of Oral Science. 2015;57(3):255-261.

4. Zhang Y, Lee JJ-W, Srikanth R, Lawn BR. Edge chipping and flexural resistance of Monolithic ceramics. Dental Materials. 2013;29:1201-8

5. Kern M, Sasse M, Wolfart S. Ten-year outcome of three-unit fixed dental prostheses made from monolithic lithium disilicate ceramic. The Journal of the American Dental Association. 2012;143(3):234-24.

6. Zarone F, Ferrari M, Mangano FG, Leone R, Sorrentino R. "Digitally Oriented Materials": Focus on Lithium Disilicate Ceramics. International Journal of Dentistry. 2016.

7. Song X-F, Rena H-T, Yin L. Machinability of lithium disilicate glass ceramic in in vitro dental diamond bur adjusting process. Journal of the Mechanical Behavior of Biomedical Materials. 2016;53:78-92.

8. Keshvad A, Hooshmand T, Asefzadeh F, Khalilinejad F, Alihemmati M, Van Noort R. Marginal Gap, Internal Fit, and Fracture Load of Leucite-Reinforced Ceramic Inlays Fabricated by CEREC inLab and Hot-Pressed Techniques. Journal of Prosthodontics. 2011;20(7):535-40 
9. Rekow D, Zhang Y, Thompson V. Can material properties predict survival of allceramic posterior crowns? Compendium of Continuing Education in Dentistry. 2007;28(7):362-8.

10. Thompson VP, Rekow DE. Dental ceramics and the molar crown testing ground. Journal of Applied Oral Science. 2004;12(spe):26-36.

11. Pieger S, Salman A, Bidra AS. Clinical outcomes of lithium disilicate single crowns and partial fixed dental prostheses: A systematic review. The Journal of Prosthetic Dentistry. 2014;112(1):22-30.

12. Araujo NS, Moda MD, Silva EA, Zavanelli AC, Quinelli Mazaro JV, Pellizzer EP. Survival of all-ceramic restorations after a minimum follow-up of five years: A systematic review. Quintessence International. 2016;47(5):395-405

13. Richter WA, Ueno H. Relationship of crown margin placement to gingival inflammation. Journal of Prosthetic Dentistry. 1973;30(2):156-61.

14. Bader JD, Rozier RG, McFall WT, Ramsey DL. Effect of crown margins on periodontal conditions in regularly attending patients. Journal of Prosthetic Dentistry. 1991;65(1):75-9.

15. Knoernschild KL, Campbell SD. Periodontal tissue responses after insertion of artificial crowns and fixed partial dentures. Journal of Prosthetic Dentistry. 2000;84(5):492-8. 16. Yildiz C, Vanlioglu BA, Evren B, Uludamar A, Ozkan YK. Marginal-internal adaptation and fracture resistance of CAD/CAM crown restorations. Dental Materials Journal. 2013;32(1):42-7.

17. Hamza TA, Ezzat HA, El-Hossary MMK, Katamish HAEM, Shokry TE, Rosenstiel SF. Accuracy of ceramic restorations made with two CAD/CAM systems. Journal of Prosthetic Dentistry. 2013;109(2):83-7. 
18. Groten M, Girthofer S, Probster L. Marginal fit consistency of copy-milled all-ceramic crowns during fabrication by light and scanning electron microscopic analysis in vitro. Journal of Oral Rehabilitation. 1997;24(12):871-81.

19. Beschnidt SM, Strub JR. Evaluation of the marginal accuracy of different all-ceramic crown systems after simulation in the artificial mouth. Journal of Oral Rehabilitation. 1999;26(7):582-93.

20. Alghazzawi TF, Liu P-R, Essig ME. The Effect of Different Fabrication Steps on the Marginal Adaptation of Two Types of Glass-Infiltrated Ceramic Crown Copings Fabricated by CAD/CAM Technology. Journal of Prosthodontics-Implant Esthetic and Reconstructive Dentistry. 2012;21(3):167-72.

21. Holand W, Schweiger M, Rheinberger VM, Kappert H. Bioceramics and their applications for dental restoration. Advances in Applied Ceramics. 2009;108:373-80.

22. Liu D, Matinlinna JP, Pow EHN. Insights into porcelain zirconia bonding. Journal of Adhesion Science and Technology. 2012;26:1249-65.

23. Abduo J, Lyons K, Swain M. Fit of zirconia fixed partial denture: a systematic review. Journal of Oral Rehabilitation. 2010;37(11):866-76.

24. Kelly JR, Benetti P. Ceramic materials in dentistry: historical evolution and current practice. Australian Dental Journal. 2011;56(Suppl. 1):84-96.

25. Miyazaki T, Hotta Y, Kunii J, Kuriyama S, Tamaki Y. A review of dental CAD/CAM: current status and future perspectives from 20 years of experience. Dental Materials Journal. $2009 ; 28(1): 44-56$.

26. Shearer AC, Heymann HO, Wilson NH. Two ceramic materials compared for the production of CEREC inlays. Journal of Dentistry. 1993; 21(5):302-304.

27. Bosch G, Ender A, Mehl A. A 3-dimensional accuracy analysis of chairside CAD/CAM milling processes. The Journal of Prosthetic Dentistry. 2014;112(6):1425-1431. 
28. Roperto R, Assaf H, Porto TS, Lang L, Teich S. Are different generations of CAD/CAM milling machines capable to produce restorations with similar quality? Journal of Clinical and Experimental Dentistry. 2016;8(4):423-428.

29. Tsitrou EA, Northeast SE, van Noort R. Brittleness index of machinable dental materials and its relation to the marginal chipping factor. Journal of Dentistry. 2007;35(12):897-902.

30. Giannetopoulos S, van Noort R, Tsitrou E. Evaluation of the marginal integrity of ceramic copings with different marginal angles using two different CAD/CAM systems. ournal of Dentistry. 2010;38(12):980-986.

31. Wang H, Aboushelib MN, Feilzer AJ. Strength influencing variables on CAD/CAM zirconia frameworks. Dental Materials. 2008;24(5):633-638.

32. Zhang Y, Sailer I, Lawn BR. Fatigue of dental ceramics. Journal of Dentistry. 2013;41(12):1135-1147.

33. Rekow ED, Silva NRFA, Coelho PG, Zhang Y, Guess P, Thompson VP. Performance of Dental Ceramics: Challenges for Improvements. Jornal of Dental Research. 2011;90(8):937-952.

34. Yin L, Song XF, Song YL, Huang T, Li J. An overview of in vitro abrasive finishing \& $\mathrm{CAD} / \mathrm{CAM}$ of bioceramics in restorative dentistry. International Journal of Machine Tools \& Manufacture. 2006;46:1013-1026.

35. Patterson Companies, INC Copyright 2015 [homepage]. Acess April 28th, 2017. Available in:. https://pattersonsupport.custhelp.com/

36. Kim JW, Covel NS, Guess PC, Rekow ED, Zhang Y. Concerns of hydrothermal degradation in CAD/CAM zirconia. Journal of Dental Research. 2010;89(1):91-95. 
37. Andersson M, Carlsson L, Persson M, Bergman B. Accuracy of machine milling and spark erosion with a CAD/CAM system. The Journal of Prosthetic Dentistry. 1996;76:187193. 


\section{LEGENDS FOR ILLUSTRATIONS}

Figure 1 - Prepared artificial tooth positioned in a mannequin.

Figure 2 - Master die.

Figure 3 - Lithium disilicate glass-ceramic crowns.

Figure 4 - Stereomicroscope Stemi 2000-C (Zeiss, Oberkochen, Alemanha).

Figure 5 - Bases of polyvinyl siloxane (Express; 3M ESPE, St Paul, USA).

Figure 6 - Crowns positioned in base

Figure 7 - Image overlapping on Adobe Photoshop CS6 software.

Figure 8 - Measures of ImageJ software.

Figure 9 - Example of perfect margin

Figure 10 - Example of marginal chipping

Figure 11 - Chipping Factor (CF) analysis 


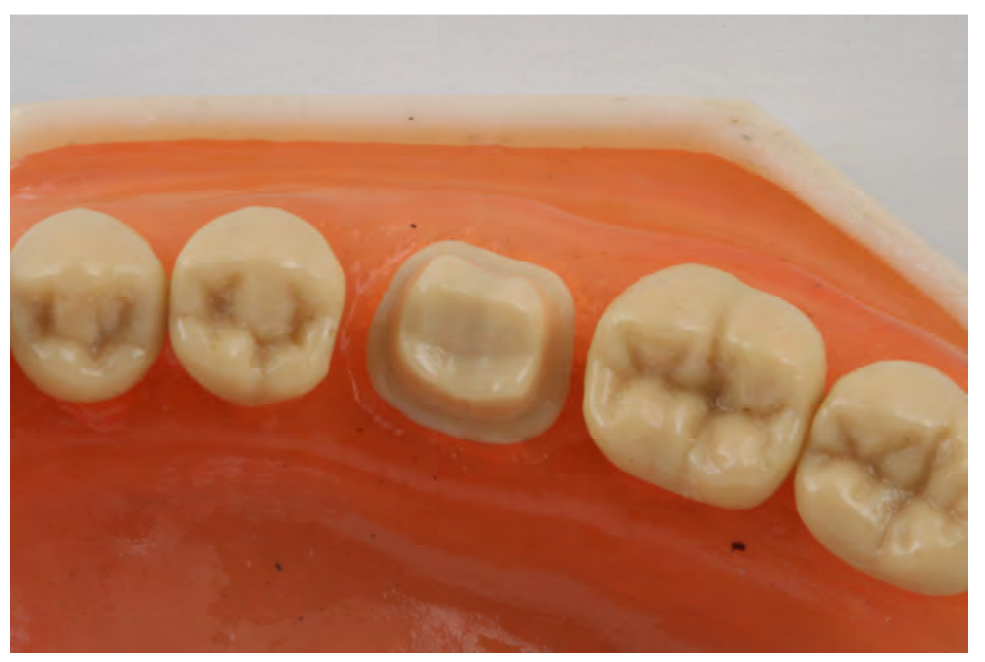

Fig 1 
Fig 2

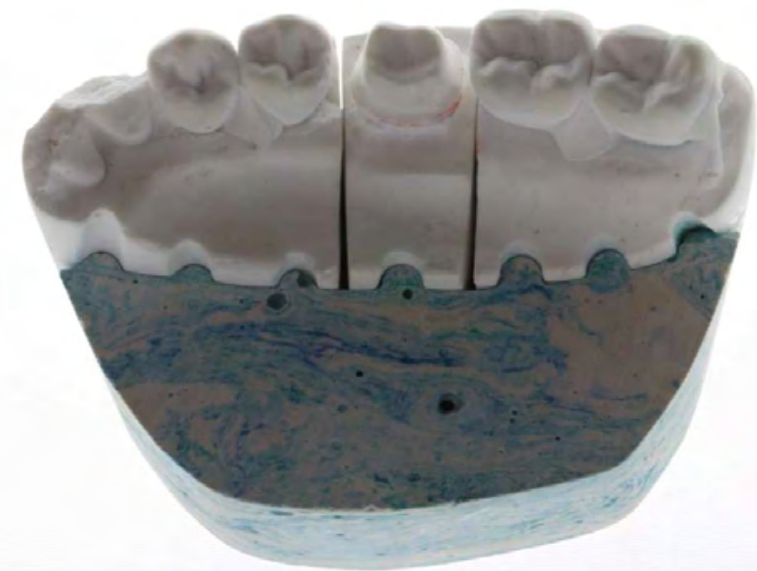



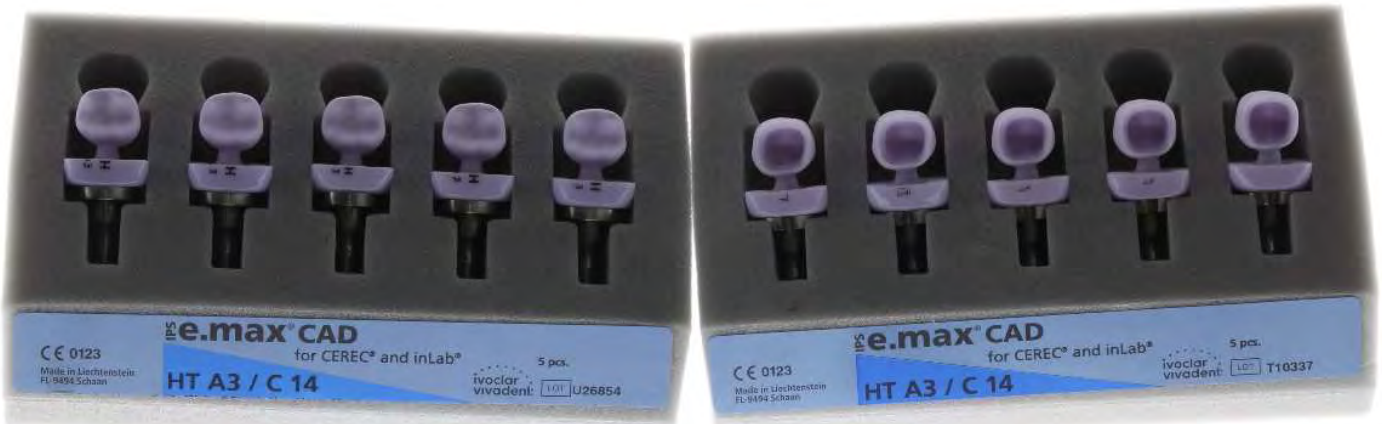

Fig 3 


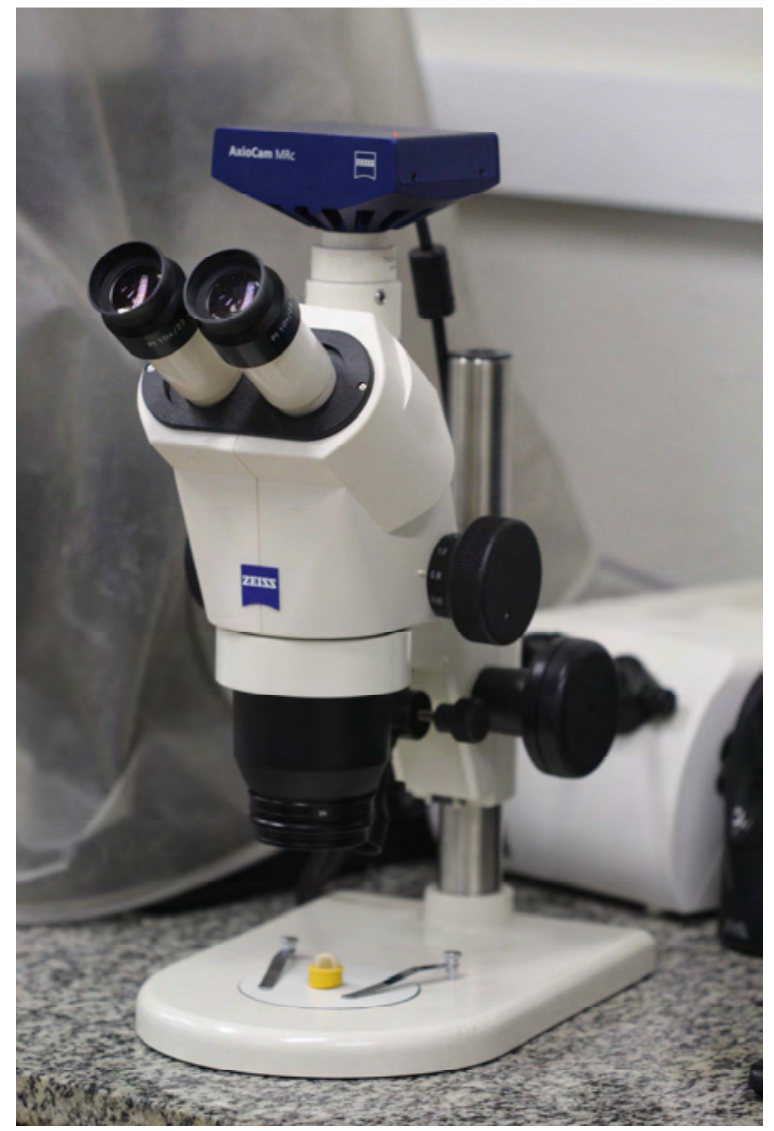

Fig 4 
Fig 5

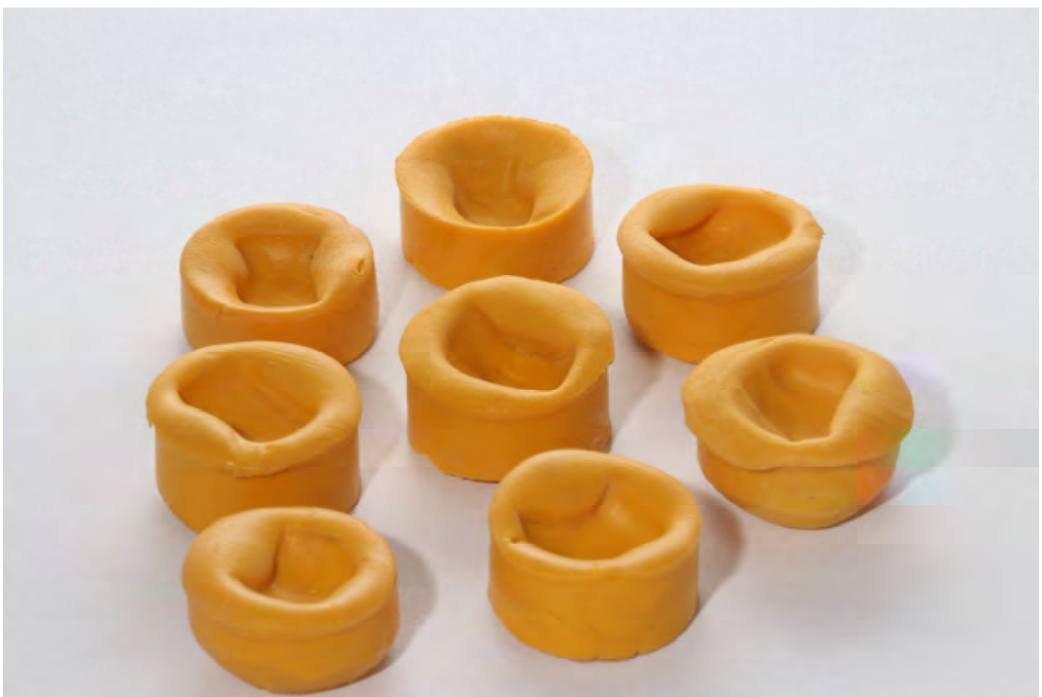




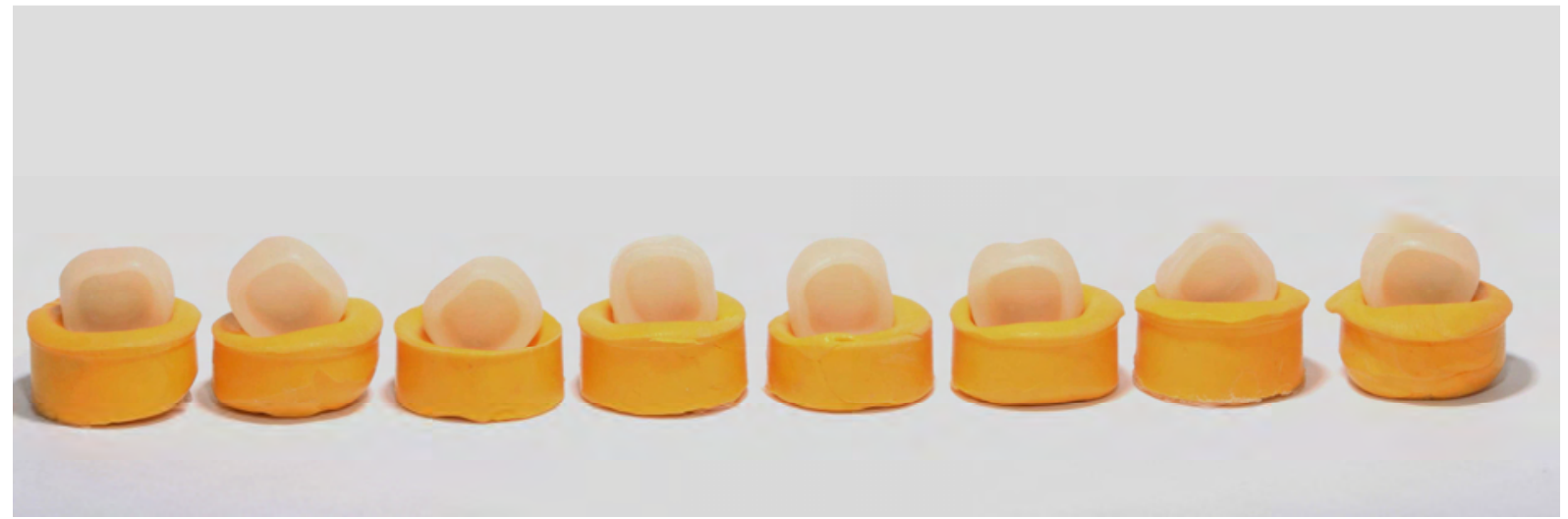

Fig 6 

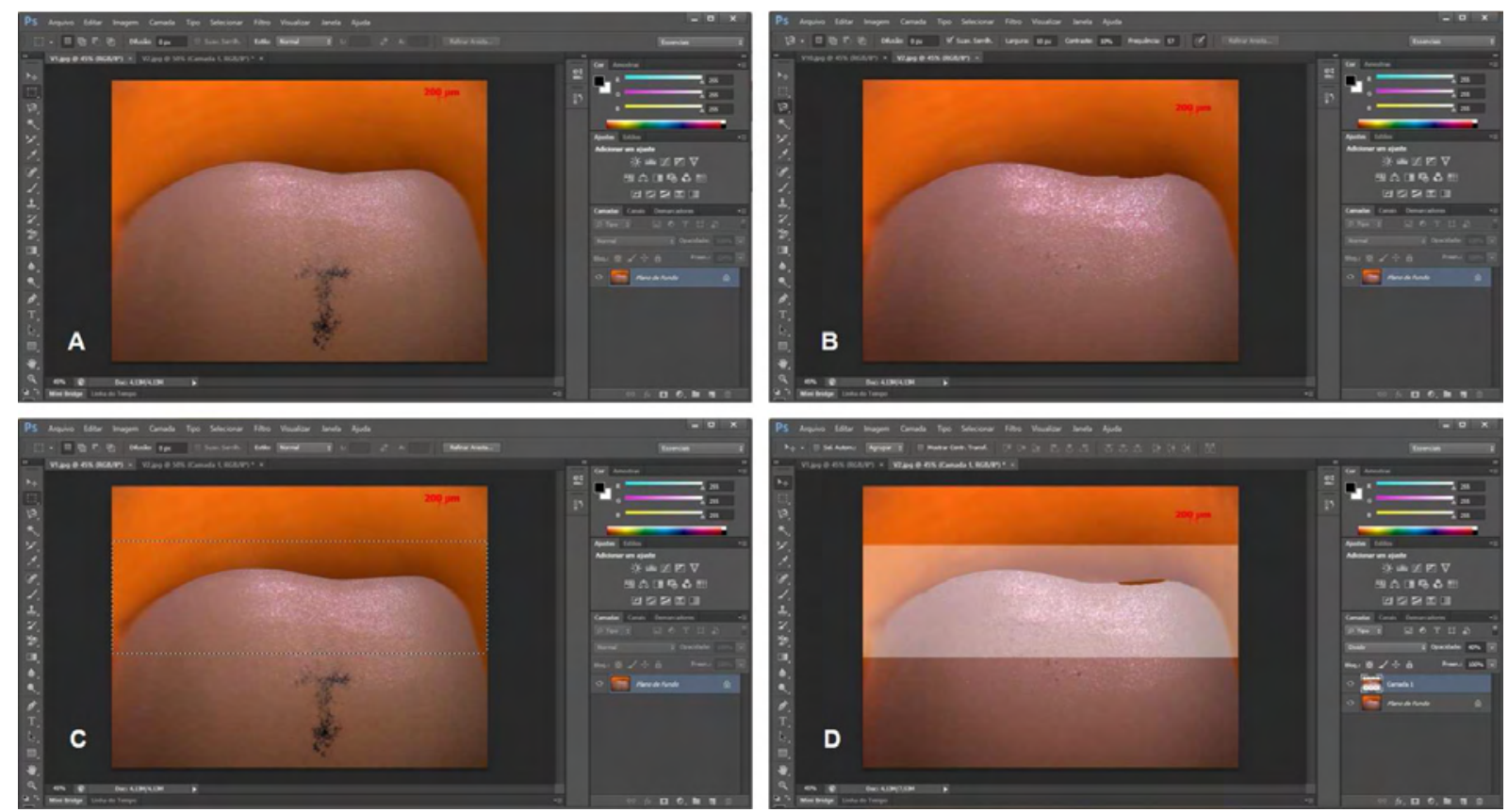

Fig 7 

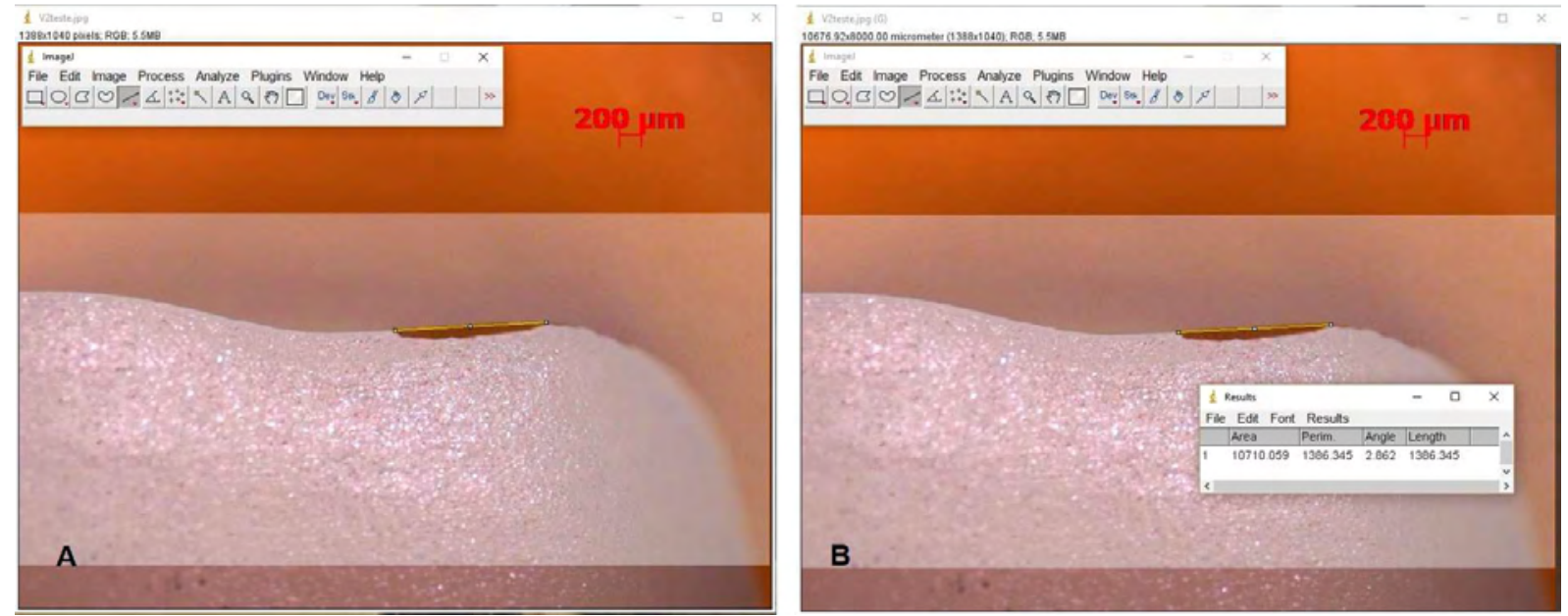

Fig 8 
Fig 9 


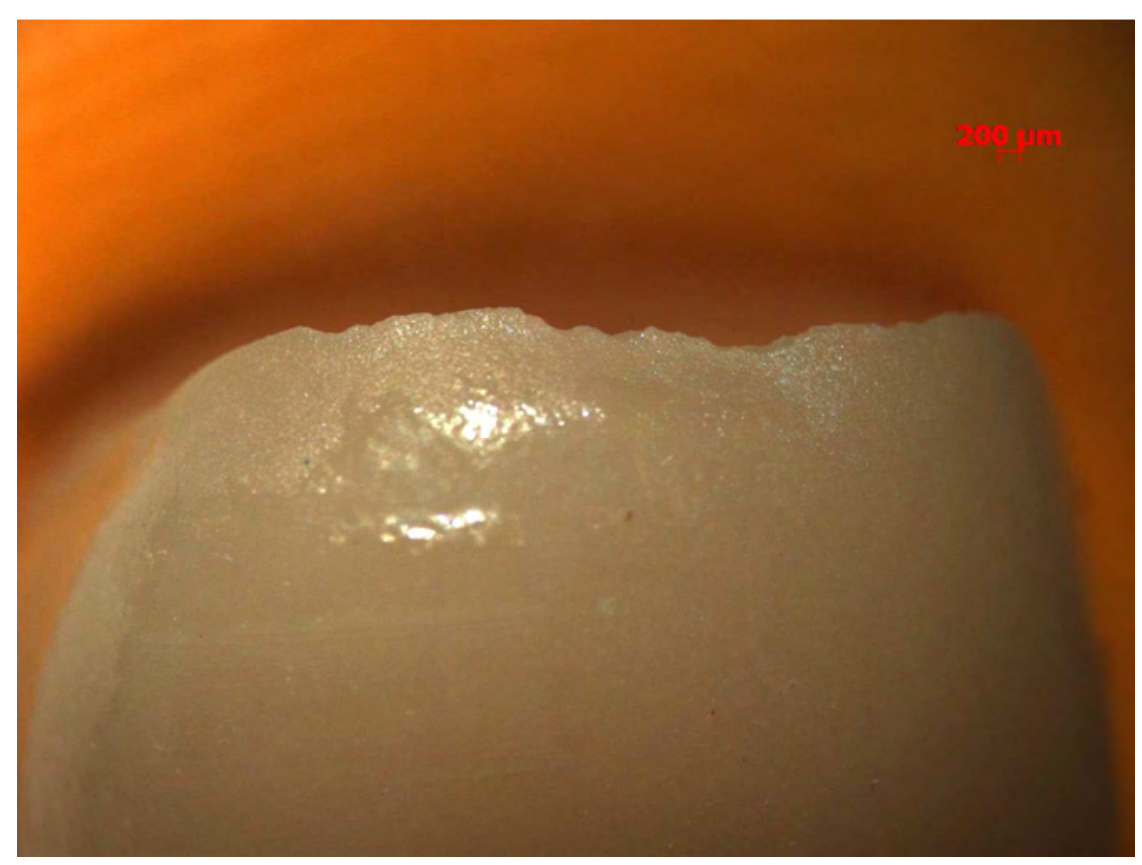

Fig 10 


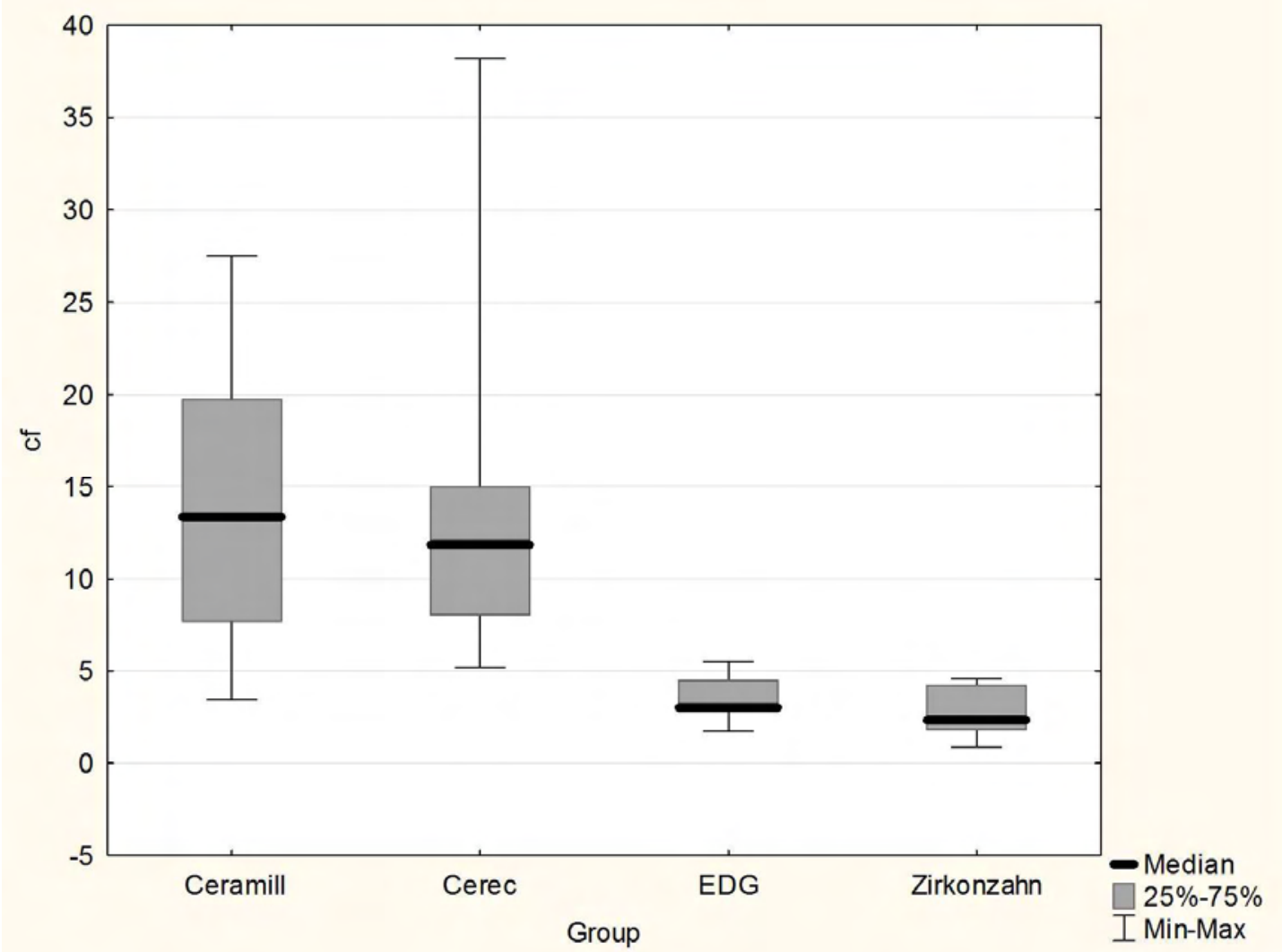

Fig 11 
Table 1. Mean CF and standard deviation of CAD/CAM systems

CAD/CAM SYSTEM

\begin{tabular}{c|cc}
\hline CERAMILL & 14,5 & 8,3 \\
CEREC & 13,4 & 9,4 \\
EDG & 3,4 & 1,2 \\
ZIRKONZAHN & 2,8 & 1,3 \\
\hline
\end{tabular}

\section{MEAN CF}

SD 
3 DiscussiON 



\section{DISCUSSION}

Prosthesis longevity can be affected by many factors, including marginal adaptation, internal fit and the quality of laboratory processing. ${ }^{11-13}$ If the marginal integrity presents discrepancies or gaps, it will directly influence the marginal adaptation and might result in higher susceptibility to secondary caries, plaque retention, marginal discoloration and also prevent the final adjustment. ${ }^{16-23}$

In this in vitro study, the marginal integrity of monolithic lithium disilicate (IPS e.max CAD) crowns manufactured by four different CAD/CAM systems was evaluated by quantitative image analysis, in order to determine if there is a difference in this characteristic among manufacturing systems.

The index used to determine de marginal integrity was the chipping factor (CF). The results showed an increase of the CF in CEREC $(13,35 \%)$ and Ceramill $(11,84 \%)$ groups. On the other hand, the EDG (3,02\%) and Zirkonzahn (2,33\%) groups presented lower CF rates. Multiple comparison analyses presented statistically significant differences between the groups with high and low CF $(p<0,05)$.

The data obtained in CEREC and Ceramill groups are opposite to a previous study using copings, which present lower values of CF. ${ }^{45}$ Direct comparison can be realized in CEREC group with $0^{\circ}$ bevel angle copings, where the mean CF was 2,8\% compared with $13,35 \%$ found by this study. It is important to emphasize that the difference of design between copings and crowns may affect the results, since the CAD-CAM manufacturing process produce in copings a collar at the margins, which function as a support while the crowns are milled until the final shape, increasing the possibility of marginal chipping. ${ }^{45}$

Tsitrou et al. ${ }^{44}$ correlated the machinability of glass ceramic materials through the chipping factor and brittleness calculation by single CAD/CAM system. They used the CEREC system to mill lithium disilicate crowns finding $69.8 \%$ of marginal chipping, which was significantly greater than present study. Moreover, their results showed a perfect positive correlation between brittleness and CF, however, in this study only one glass ceramic was used, which standardized the samples. Another finding to emerge from the analysis is related to occurrence of differences in milling process of CAD/CAM systems which have different effects on the quality of the restorations. 
The variations between groups could be related to the machinability of CAD/CAM systems. The machining processes create, through the milling burs contact, trace lines inducing few microscopic defects. Although microscopic, these defects, represented by sharp cracks and scratches, promote surface damages that enable stress concentration increasing the susceptibility for crack initiation that, in turn, may increase with mastication. Therefore, microscopic flaws lead to small cracks, which can grow and result in larger cracks reducing strength and fatigue life or even causing catastrophic failure. ${ }^{46-49}$

The marginal thickness is another relevant issue that requires attention. Usually, the studies do not exhibit this information, which is essential for this type of evaluation. According to the manufacturing companies, the amount of ceramic present at the margin of the restoration can vary without affecting the adaptation. It is supposed that a smaller thickness of material in margin may turn the margin of restoration more susceptible to damage derived from the milling process.

The margin ramp width also is an important factor, since it establishes the length of the area that the restoration rises from the dental preparation. Minimally invasive preparation must maintain sufficient space to guarantee the adequate ceramic properties, however the reduced width of finish lines produce restorations with low thickness, which may hamper the manufacture. Furthermore, the burs diameter of CAD/CAM systems cannot be compatible with the thickness restoration and provide damages in milling resulting in margins defects.

The extension of damage can be influenced by the size of the bur, wear of the cutting tool, number of axes, applied load and grinding speed. ${ }^{38,50-52}$ The size of the burs limites the accuracy of the milling process, since the crowns fine details can be incompatible with them. ${ }^{52}$ In this study, the burs indicated by each system were used considering the fabrication of a monolithic lithium disilicate crown. For the CEREC system two burs were used, one with ,31 mm diameter (Step Bur 12S, ref. 6240167) and the other with 1,8mm (Cylinder Pointed Bur 12S, ref. 6240159). ${ }^{53}$ For the Ceramill system were used four burs with 0,4mm (ref. 760627), 1mm (ref. 760624), 1,4mm (ref. 760625) and 1,8mm (ref. 760626) diameter. ${ }^{54}$ For EDG, Ball Nouse burs with $1 \mathrm{~mm}$, $1,5 \mathrm{~mm}$ and 2,5mm diameter were used and for Zirkonzahn, 0,6 $\mathrm{mm}$ (ref. ZBAC2006), 1,25 mm (ref. ZBAC2016) and 2,5mm diameter (ref. ZBAC2026). ${ }^{55}$

Regarding to number of axes, all systems present 5 axes that enable linear movement and rotations in three spatial directions $X, Y, Z$. The ceramic block rotates 
around $X$ axes and milling spindle rotation around $Y$ axes. These freedom of rotation allows higher accuracy of the milled restorations. ${ }^{38,42}$ However, since the amount of rotations cannot be equal, the 5 milling axes vary among systems.

Another factor that could influence the final aspect of the margin is the time consuming for the milling operation. The shorter is the process, the is greater the production rate, although the probability for inaccuracy and marginal chipping will be higher, resulting in reduced success rate. ${ }^{42,52}$ In the present research, the time spent for manufacturing was $14 \mathrm{~min}$ (CEREC), $30 \mathrm{~min}$ (Ceramil), $30 \mathrm{~min}$ (EDG) and $40 \mathrm{~min}$ (Zirkonzahn). The CAD/CAM systems have a numerical control program, which guide the CAM to realize specific axis movements based on feed rate and specific spindle speed to rotate the milling tool. This program is not controlled for material machinability, therefore, it can be altered to create faster tool feed rates. ${ }^{56}$ Thus, the CAD/CAM systems have the option of changing the milling time, speeding up or not the process. Often, this decision is determined by the operator. Further studies, that considers these variables, need to be undertaken.

The CF method analysis was initially described by Tsitrou et al., ${ }^{44}$ who performed a series of images through digital camera of the perimeter crowns and a top view image of the margins of the restoration to measure the circumference. Afterwards, estimation of the degree of chipping factor was conducted according to equation detailed previously.

In the present study, image acquisition was a problem, since the zoom ratio hinders the detailed observation of crown margins. This complication could compromise the reliability of the measures. For this reason, a scanning stereomicroscope Stemi 2000-C was used (Zeiss, Oberkochen, Alemanha) with a sufficient zoom to analyze the margins.

Furthermore, the equation was adapted to guarantee that the chippings were measured and belonged to the right perimeter. Therefore, the perimeter extent was unique for each section. Another modification was applied to the setting of the measures, which were performed subsequently to overlaying of images allowing that all chipping areas were involved. The impossibility to predict the marginal chipping in previous method was the main reason for this change, since that calculating the CF before restorations milling was impossible. ${ }^{44}$

The correlation between the amount of degree of marginal chipping and longevity of all-ceramic restorations remains unknown. Consequently we cannot be 
assertive of what chipping percentage is necessary to affect the survival rates. ${ }^{45}$ However, previous researches have suggested the possibility of structural surface flaws acting as stress concentration sites. The stress magnitude will depend on the severity of the surface defect, thus the greater the surface defect, the higher the stress concentration. Consequently, the potential of flaws to become crack initiation sites, affecting survival probability increases. ${ }^{46}$ The occurrence of these defects can be related to the manufacturing process or masticatory load after cementation, since that leads to microstructural defects within the ceramic. Furthermore, flaws may assume the form of micro cracks and are unlikely to allow visual detection, due their submillimeter scale. ${ }^{47}$

Therefore, understanding the damages produced by CAD/CAM milling, it is important to highlight the marginal integrity role in success of ceramic restorations. It is necessary greater emphasis in parameters selection during the design process to guarantee better results of marginal adaptation, marginal integrity and internal fit. Future investigations could clarify questions about the theme. 
4 FINAL CONSIDERATIONS 



\section{FINAL CONSIDERATIONS}

The present study was designed to determine the degree of marginal chipping of lithium disilicate crowns manufactured by four different CAD/CAM systems and evaluate the accuracy of its production.

Within the limitations of this in vitro study and the lack of detailed information about some CAD/CAM systems, it was concluded that the chipping factor of monolithic lithium disilicate crowns exhibit statistical differences among the test groups $(p<0.001)$. Zirkonzahn showed the uniform distribution and the lowest percentage of chipping in marginal region. The current data highlight the influence of the restorations design, settings and tools of CAD/CAM systems have in final integrity of the prosthesis margin.

Furthermore, the clinical importance of chipping margin remains unclear, which suggests future in vivo studies to evaluate the marginal chipping and clinical performance of monolithic crowns made from different CAD-CAM systems. 

REFERENCES 



\section{REFERENCES}

1. Pilathadka S, Vahalová D. Contemporary all-ceramic systems, part-2. Acta Medica (Hradec Kralove). 2007;50(2):105-107.

2. Shenoy A, Shenoy N. Dental ceramics: An update. J Conserv Dent. 2010;13(4):195-203.

3. Lawson NC, Burgess JO. Dental Ceramics: A Current Review. Compend Contin Educ Dent. 2014;35(3):161-6.

4. Chan $\mathrm{C}$, Weber $\mathrm{H}$. Plaque retention on teeth restored with full-ceramic crowns: a comparative study. J Prosthet Dent. 1986;56:666-71.

5. Schultheis S, Strub JR, Gerds TA, Guess PC. Monolithic and bi-layer CAD/CAM lithium-disilicate versus metal-ceramic fixed dental prostheses: Comparison of fracture loads and failure modes after fatigue. Clin Oral Invest. 2013;17:1407-1413.

6. Seydler B, Rues S, Müller D, Schmitter M. In vitro fracture load of monolithic lithium disilicate ceramic molar crowns with different wall thicknesses. Clin Oral Invest. 2014;18:1165-1171.

7. Nordahl N, von Steyern PV, Larsson C. Fracture strength of ceramic monolithic crown systems of different thickness. J Oral Sci. 2015;57(3):255-61.

8. Kern M, Sasse M, Wolfart S. Ten-year outcome of three-unit fixed dental prostheses made from monolithic lithium disilicate ceramic. J Am Dent Assoc. 2012;143(3):234-40.

9. Zarone F, Ferrari M, Mangano FG, Leone R, Sorrentino R. "Digitally Oriented Materials": Focus on Lithium Disilicate Ceramics. International Journal of Dentistry. 2016.

10. Song X-F, Rena H-T, Yin L. Machinability of lithium disilicate glass ceramic in in vitro dental diamond bur adjusting process. J Mech Behav Biomed Mater. 2016;53:78-92.

11. Keshvad A, Hooshmand T, Asefzadeh F, Khalilinejad F, Alihemmati M, Van Noort R. Marginal Gap, Internal Fit, and Fracture Load of Leucite-Reinforced 
Ceramic Inlays Fabricated by CEREC inLab and Hot-Pressed Techniques. J Prosthodont. 2011;20(7):535-40.

12. Rekow D, Zhang $\mathrm{Y}$, Thompson V. Can material properties predict survival of allceramic posterior crowns? Compend Contin Educ Dent. 2007;28(7):362-8.

13. Thompson VP, Rekow DE. Dental ceramics and the molar crown testing ground. J Appl Oral Sci. 2004;12(spe):26-36.

14. Pieger S, Salman A, Bidra AS. Clinical outcomes of lithium disilicate single crowns and partial fixed dental prostheses: A systematic review. J Prosthet Dent. 2014;112(1):22-30.

15. Araujo NS, Moda MD, Silva EA, Zavanelli AC, Quinelli Mazaro JV, Pellizzer EP. Survival of all-ceramic restorations after a minimum follow-up of five years: $A$ systematic review. Quintessence Int. 2016;47(5):395-405

16. Richter WA, Ueno $H$. Relationship of crown margin placement to gingival inflammation. J Prosthet Dent. 1973;30(2):156-61

17. Bader JD, Rozier RG, McFall WT, Ramsey DL. Effect of crown margins on periodontal conditions in regularly attending patients. $\mathrm{J}$ Prosthet Dent. $1991 ; 65(1): 75-9$

18. Knoernschild KL, Campbell SD. Periodontal tissue responses after insertion of artificial crowns and fixed partial dentures. J Prosthet Dent. 2000;84(5):492-8

19. Yildiz C, Vanlioglu BA, Evren B, Uludamar A, Ozkan YK. Marginal-internal adaptation and fracture resistance of CAD/CAM crown restorations. Dent Mater J. 2013;32(1):42-7

20. Hamza TA, Ezzat HA, El-Hossary MMK, Katamish HAEM, Shokry TE, Rosenstiel SF. Accuracy of ceramic restorations made with two CAD/CAM systems. J Prosthet Dent. 2013;109(2):83-7.

21. Groten M, Girthofer S, Probster L. Marginal fit consistency of copy-milled allceramic crowns during fabrication by light and scanning electron microscopic analysis in vitro. J Oral Rehabil. 1997;24(12):871-81

22. Beschnidt SM, Strub JR. Evaluation of the marginal accuracy of different allceramic crown systems after simulation in the artificial mouth. J Oral Rehabil. 1999;26(7):582-93 
23. Alghazzawi TF, Liu P-R, Essig ME. The effect of different fabrication steps on the marginal adaptation of two types of glass-infiltrated ceramic crown copings fabricated by CAD/CAM technology. J Prosthodont. 2012;21(3):167-72.

24. Boitelle P, Mawussi B, Tapie L, Fromentin O. A systematic review of CAD/CAM fit restoration evaluations. J Oral Rehabil. 2014;41(11):853-74.

25. Ortorp A, Jonsson D, Mouhsen A, von Steyern PV. The fit of cobalt-chromium three-unit fixed dental prostheses fabricated with four different techniques: $A$ comparative in vitro study. Dent Mater. 2011;27(4):356-63

26. Suleiman $\mathrm{SH}$, von Steyern PV. Fracture strength of porcelain fused to metal crowns made of cast, milled or laser-sintered cobalt-chromium. Acta Odontol Scand. 2013;71(5):1280-9.

27. Willer J, Rossbach A, Weber HP. Computer-assisted milling of dental restorations using a new CAD/CAM data acquisition system. J Prosthet Dent. 1998;80(3):346-53.

28. Akova T, Ucar Y, Tukay A, Balkaya MC, Brantley WA. Comparison of the bond strength of laser-sintered and cast base metal dental alloys to porcelain. Dent Mater. 2008;24(10):1400-4.

29. Lee D-H, Lee B-J, Kim S-H, Lee K-B. Shear bond strength of porcelain to a new millable alloy and a conventional castable alloy. $J$ Prosthet Dent. 2015;113(4):329-35.

30. Miyazaki T, Hotta Y. CAD/CAM systems available for the fabrication of crown and bridge restorations. Aust Dent J. 2011;56:(1 Suppl):97-106.

31. Holand W, Schweiger M, Rheinberger VM, Kappert H. Bioceramics and their applications for dental restoration. Adv Appl Ceram. 2009;108:373-80

32. Liu D, Matinlinna JP, Pow EHN. Insights into porcelain zirconia bonding. J Adhes Sci Technol. 2012;26:1249-65.

33. Abduo J, Lyons K, Swain M. Fit of zirconia fixed partial denture: a systematic review. J Oral Rehabil. 2010;37:866-76.

34. Kelly JR, Benetti P. Ceramic materials in dentistry: historical evolution and current practice. Aust Dent J. 2011;56(Suppl. 1):84-96. 
35. Kapos T, Evans C. CAD/CAM Technology for Implant Abutments, Crowns, and Superstructures. Int J Oral Maxillofac Implants. 2014;29(suppl):117-136.

36. Davidowitz G, Kotick PG. The use of CAD/CAM in dentistry. Dent Clin North Am. 2011;55(3):559-570.

37. Miyazaki T, Hotta Y, Kunii J, Kuriyama S, Tamaki Y. A review of dental CAD/CAM: current status and future perspectives from 20 years of experience. Dent Mater J. 2009;28(1):44-56.

38. Alghazzawi TF. Advancements in CAD/CAM technology: Options for practical implementation. J Prosthodont Res. 2016;60(2):72-84.

39. Kirsch C, Ender A, Attin T. Trueness of four different milling procedures used in dental CAD/CAM systems. Clin Oral Investig. 2016;21(2):551-558.

40. Pjetursso BE, Sailer I, Makarov NA, Zwahlen M, Thoma DS. All-ceramic or metal-ceramic tooth-supported fixed dental prostheses (FDPs)? A systematic review of the survival and complication rates. Part II: Multiple-unit FDPs. Dent Mater. 2015;31(6):624-639.

41. Shearer AC, Heymann HO, Wilson NH. Two ceramic materials compared for the production of CEREC inlays. J Dent. 1993; 21(5):302-304.

42. Bosch G, Ender A, Mehl A. A 3-dimensional accuracy analysis of chairside CAD/CAM milling processes. J Prosthet Dent. 2014;112(6):1425-1431.

43. Roperto R, Assaf H, Porto TS, Lang L, Teich S. Are different generations of CAD/CAM milling machines capable to produce restorations with similar quality? J Clin Exp Dent. 2016;8(4):423-428.

44. Tsitrou EA, Northeast SE, van Noort R. Brittleness index of machinable dental materials and its relation to the marginal chipping factor. $J$ Dent. 2007;35(12):897-902.

45. Giannetopoulos S, van Noort R, Tsitrou E. Evaluation of the marginal integrity of ceramic copings with different marginal angles using two different CAD/CAM systems. J Dent. 2010;38(12):980-986.

46. Wang $\mathrm{H}$, Aboushelib $\mathrm{MN}$, Feilzer AJ. Strength influencing variables on CAD/CAM zirconia frameworks. Dent Mater. 2008;24(5):633-638. 
47. Zhang Y, Sailer I, Lawn BR. Fatigue of dental ceramics. J Dent. 2013;41(12):1135-1147.

48. Rekow ED, Silva NRFA, Coelho PG, Zhang Y, Guess P, Thompson VP. Performance of dental ceramics: challenges for improvements. J Dent Res. 2011;90(8):937-952.

49. Yin L, Song XF, Song YL, Huang T, Li J. An overview of in vitro abrasive finishing \& CAD/CAM of bioceramics in restorative dentistry. International Journal of Machine Tools \& Manufacture. 2006;46(9):1013-1026.

50. Song XF, Rena H-T, Yin L. Machinability of lithium disilicate glass ceramic in in vitro dental diamond bur adjusting process. J Mech Behav Biomed Mater. 2016;53:78-92.

51. Kim JW, Covel NS, Guess PC, Rekow ED, Zhang Y. Concerns of hydrothermal degradation in CAD/CAM zirconia. J Dent Res. 2010;89(1):91-95..

52. Andersson M, Carlsson L, Persson M, Bergman B. Accuracy of machine milling and spark erosion with a CAD/CAM system. J Prosthet Dent. 1996;76:187-193.

53. Patterson Companies, INC [homepage]. Acess April 28th, 2017. Available in: https://pattersonsupport.custhelp.com/.

54. Amann Girrbach Brasil LTDA [homepage]. Acess April 28th, 2017. Available in: https://br.amanngirrbach.com/

55. Talmax - Produtos para Prótese Odontológica [homepage]. Acess April 28th, 2017. Available in: http://www.talmax.com.br

56. Chavali R, Nejat AH, Lawson NC. Machinability of CAD-CAM materials. J Prosthet Dent. 2016:1-6. 




\section{ANNEX A - Guidelines for The Journal of Prosthetic Dentistry:}

\section{Submission Gujdelines}

Thank you for your interest in writing an article for The Journal of Prosthetic Dentistry. In publishing, as in dentistry, precise procedures are essential. Your attention to and compliance with the following policies will help ensure the timely processing of your submission.

\section{Length of Manuscripts}

Manuscript length depends on manuscript type. In general, research and clinical science articles should not exceed 10 to 12 double-spaced, typed pages (excluding references, legends, and tables). Clinical Reports and Technique articles should not exceed 4 to 5 pages, and Tips articles should not exceed 1 to 2 pages. The length of systematic reviews varies.

\section{Number of Authors}

The number of authors is limited to 4 ; the inclusion of more than 4 must be justified in the letter of submission. (Each author's contribution must be listed.) Otherwise, contributing authors in excess of 4 will be listed in the Acknowledgments. There can only be one corresponding author.

\section{General Formatting}

All submissions must be submitted via the EES system in Microsoft Word with an $8.5 \times 11$ inch page size. The following specifications should also be followed:

Times Roman, 12 ptDouble-spacedLeft-justifiedNo space between paragraphs1-inch margins on all sidesHalf-inch paragraph indentsHeaders/Footers should be clear of page numbers or other informationHeadings are upper case bold, and subheads are upper/lower case bold. No italics are used.References should not be automatically numbered. Endnote or other reference-generating programs should be turned off.Set the Language feature in MS Word to English (US). Also change the language to English (US) in the style named Balloon Text.

\section{Ethics in publishing}

Please see our information pages on Ethics in publishing and Ethical guidelines for journal publication.

\section{Declaration of interest}

All authors must disclose any financial and personal relationships with other people or organizations that could inappropriately influence (bias) their work. Examples of potential conflicts of interest include employment, consultancies, stock ownership, honoraria, paid expert testimony, patent applications/ registrations, and grants or other funding. If there are no conflicts of interest then please state this: 'Conflicts of interest: none'. More information.

\section{Submission declaration}

Submission of an article implies that the work described has not been published previously (except in the form of an abstract or as part of a published lecture or academic thesis or as an electronic preprint, see 'Multiple, redundant or concurrent publication' section of our ethics policy for more information), that it is not under consideration for publication elsewhere, that its publication is approved by all authors and tacitly or explicitly by the responsible authorities where the work was carried out, and that, if accepted, it will not be published elsewhere including electronically in the same form, in English or in any other language, without the written consent of the copyright-holder.

\section{Changes to authorship}

Authors are expected to consider carefully the list and order of authors before submitting their manuscript and provide the definitive list of authors at the time of the original submission. Any addition, deletion or rearrangement of author names in the authorship list should be made only before the manuscript has been accepted and only if approved by the journal Editor. To request such a change, the Editor must receive the following from the corresponding author: (a) the reason for the change in author list and (b) written confirmation (e-mail, letter) from all authors that they agree with the addition, removal or rearrangement. In the case of addition or removal of authors, this includes confirmation from the author being added or removed.

Only in exceptional circumstances will the Editor consider the addition, deletion or rearrangement of authors after the manuscript has been accepted. While the Editor considers the request, publication of the manuscript will be suspended. If the manuscript has already been published in an online issue, any requests approved by the Editor will result in a corrigendum. 


\section{Copyright}

Upon acceptance of an article, authors will be asked to complete a 'Journal Publishing Agreement' (see more information on this). An e-mail will be sent to the corresponding author confirming receipt of the manuscript together with a 'Journal Publishing Agreement' form or a link to the online version of this agreement.

Subscribers may reproduce tables of contents or prepare lists of articles including abstracts for internal circulation within their institutions. Permission of the Publisher is required for resale or distribution outside the institution and for all other derivative works, including compilations and translations. If excerpts from other copyrighted works are included, the author(s) must obtain written permission from the copyright owners and credit the source(s) in the article. Elsevier has preprinted forms for use by authors in these cases.

For open access articles: Upon acceptance of an article, authors will be asked to complete an 'Exclusive License Agreement' (more information). Permitted third party reuse of open access articles is determined by the author's choice of user license.

\section{Author rights}

As an author you (or your employer or institution) have certain rights to reuse your work. More information.

\section{Elsevier supports responsible sharing}

Find out how you can share your research published in Elsevier journals.

\section{Role of the funding source}

You are requested to identify who provided financial support for the conduct of the research and/or preparation of the article and to briefly describe the role of the sponsor(s), if any, in study design; in the collection, analysis and interpretation of data; in the writing of the report; and in the decision to submit the article for publication. If the funding source(s) had no such involvement then this should be stated.

Funding body agreements and policies

Elsevier has established a number of agreements with funding bodies which allow authors to comply with their funder's open access policies. Some funding bodies will reimburse the author for the Open Access Publication Fee. Details of existing agreements are available online.

\section{Creative Commons Attribution (CC BY)}

Lets others distribute and copy the article, create extracts, abstracts, and other revised versions, adaptations or derivative works of or from an article (such as a translation), include in a collective work (such as an anthology), text or data mine the article, even for commercial purposes, as long as they credit the author(s), do not represent the author as endorsing their adaptation of the article, and do not modify the article in such a way as to damage the author's honor or reputation.

Creative Commons Attribution-NonCommercial-NoDerivs (CC BY-NC-ND)

For non-commercial purposes, lets others distribute and copy the article, and to include in a collective work (such as an anthology), as long as they credit the author(s) and provided they do not alter or modify the article.

The open access fee for this journal is USD 2500, excluding taxes. Learn more about Elsevier's pricing policy: https://www.elsevier.com/openaccesspricing.

\section{Language (usage and editing services)}

Please write your text in good American English. Authors who feel their English language manuscript may require editing to eliminate possible grammatical or spelling errors and to conform to correct scientific English may wish to use the English Language Editing service available from Elsevier's WebShop http://webshop.elsevier.com/languageediting/ or visit our customer support site http://support.elsevier.com for more information.

\section{Informed consent and patient details}

Studies on patients or volunteers require ethics committee approval and informed consent, which should be documented in the paper. Appropriate consents, permissions and releases must be obtained where an author wishes to include case details or other personal information or images of patients and any other individuals in an Elsevier publication. Written consents must be retained by the author and copies of the consents or evidence that such consents have been obtained must be provided to 
Elsevier on request. For more information, please review the Elsevier Policy on the Use of Images or Personal Information of Patients or other Individuals. Unless you have written permission from the patient (or, where applicable, the next of kin), the personal details of any patient included in any part of the article and in any supplementary materials (including all illustrations and videos) must be removed before submission.

\section{Submission}

Our online submission system guides you stepwise through the process of entering your article details and uploading your files. The system converts your article files to a single PDF file used in the peer-review process. Editable files (e.g., Word, LaTeX) are required to typeset your article for final publication. All correspondence, including notification of the Editor's decision and requests for revision, is sent by e-mail.

Submit your article

Please submit your article via http://www.ees.elsevier.com/jpd/.

\section{PREPARATION}

Use of word processing software

It is important that the file be saved in the native format of the MS Word program. The text should be in single-column format. Keep the layout of the text as simple as possible. Most formatting codes will be removed and replaced on processing the article. In particular, do not use the word processor's options to justify text or to hyphenate words. However, do use bold face, italics, subscripts, superscripts etc. When preparing tables, if you are using a table grid, use only one grid for each individual table and not a grid for each row. If no grid is used, use tabs, not spaces, to align columns. The electronic text should be prepared in a way very similar to that of conventional manuscripts (see also the Guide to Publishing with Elsevier: http://www.elsevier.com/guidepublication). Note that source files of figures, tables and text graphics will be required whether or not you embed your figures in the text. See also the section on Electronic artwork.

To avoid unnecessary errors you are strongly advised to use the 'spell-check' and 'grammar-check' functions of your word processor.

Embedded math equations

If you are submitting an article prepared with Microsoft Word containing embedded math equations then please read this related support information (http://support.elsevier.com/app/answers/detail/a_id/302/).

\section{Essential title page information}

Title. Concise and informative. Titles are often used in information-retrieval systems. Avoid abbreviations and formulae. Trade names should not be used in the title.Author names and affiliations. Author's names should be complete first and last names. Where the family name may be ambiguous (e.g., a double name), please indicate this clearly. Present the authors' current title and affiliation, including the city and state/country of that affiliation. If it is private practice, indicate the city and state/country of the practice. Indicate all affiliations with a lower-case superscript letter immediately after the author's name and in front of the appropriate affiliation.Corresponding author. Clearly indicate who will handle correspondence at all stages of refereeing and publication, also postpublication. Ensure that phone numbers (with country and area code) are provided in addition to the e-mail address and the complete postal address. Contact details must be kept up to date by the corresponding author.

\section{Title page format}

Title: Capitalize only the first letter of the first word. Do not use any special formatting. Abbreviations or trade names should not be used. Trade names should not be used in the title.Authors: Directly under the title, type the names and academic degrees of the authors. Under the authors names, provide the title, department and institutional names, city/state and country (unless in the U.S.) of each author. If necessary, provide the English translation of the institution. If the author is in private practice, indicate where with city/state/country. Link names and affiliations with a superscript letter $(a, b, c, d)$. Presentation/support information and titles: If research was presented before an organized group, indicate name of the organization and location and date of the meeting. If work was supported by a grant or any other kind of funding, supply the name of the supporting organization and the grant 
number. Corresponding author: List the mailing address, business telephone, and e-mail address of the author who will receive correspondence. Acknowledgments: Indicate special thanks to persons or organizations involved with the manuscript. See Sample Title page.

Formatting of funding sources

List funding sources in this standard way to facilitate compliance to funder's requirements:

Funding: This work was supported by the National Institutes of Health [grant numbers xxxx, yyyy]; the Bill \& Melinda Gates Foundation, Seattle, WA [grant number zzzz]; and the United States Institutes of Peace [grant number aaaa].

It is not necessary to include detailed descriptions on the program or type of grants and awards. When funding is from a block grant or other resources available to a university, college, or other research institution, submit the name of the institute or organization that provided the funding.

If no funding has been provided for the research, please include the following sentence:

This research did not receive any specific grant from funding agencies in the public, commercial, or not-for-profit sectors.

Units

Follow internationally accepted rules and conventions: use the international system of units (SI). If other units are mentioned, please give their equivalent in SI.

Math formulae

Please submit math equations as editable text and not as images. Present simple formulae in line with normal text where possible and use the solidus $(/)$ instead of a horizontal line for small fractional terms, e.g., X/Y. In principle, variables are to be presented in italics. Powers of e are often more conveniently denoted by exp. Number consecutively any equations that have to be displayed separately from the text (if referred to explicitly in the text).

Embedded math equations

If you are submitting an article prepared with Microsoft Word containing embedded math equations then please read this (related support information).

\section{Artwork \\ Figure Submission}

JPD takes pride in publishing only the highest quality figures in its journal. All incoming figures must pass a thorough examination in Photoshop before the review process can begin. With more than 1,000 manuscripts submitted yearly, the manuscripts with few to no submission errors move through the system quickly. Figures that do not meet the guidelines will be sent back to the author for correction and moved to the bottom of the queue, creating a delay in the publishing process.

File Format

All figures should be submitted as TIF files or JPEG files only.

\section{Image File Specifications}

Figure dimensions must be $\mathbf{5 . 7 5} \times \mathbf{3 . 8 5}$ inches.

Figures should be size-matched (the same physical size) unless the image type prohibits size matching to other figures within the manuscript, as in the case of panoramic or periapical radiographs, SEM images, or graphs and screen shots. Do not "label" the faces of the figures with letters or numbers to indicate the order in which the figures should appear; such labels will be inserted during the publication process. Do not add wide borders to increase size.

\section{Resolution}

The figures should be of professional quality and high resolution. The following are resolution requirements:

Color and black-and-white photographs should be created and saved at 300 dots per inch (dpi).

Note: A $5.75 \times 3.85$-inch image at a resolution of $300 \mathrm{dpi}$ will be approximately 6 megabytes. A figure of less than $300 \mathrm{dpi}$ must not be increased artificially to $300 \mathrm{dpi}$; the resulting quality and resolution will be poor. 
Line art or combination artwork (an illustration containing both line art and photograph) should be created and saved at a minimum of $600 \mathrm{dpi}$.Clarity, contrast, and quality should be uniform among the parts of a multipart figure and among all of the figures within a manuscript.A uniform background of nontextured, medium blue should be provided for color figures when possible.

\section{Text within Images}

If text is to appear within the figure, labeled and unlabeled versions of the figures must be provided. Text appearing within the labeled versions of the figures should be in Arial font and a minimum of $10 \mathrm{pt}$. The text should be sized for readability if the figure is reduced for production in the Journal. Lettering should be in proportion to the drawing, graph, or photograph. A consistent font size should be used throughout each figure, and for all figures, Please note: Titles and captions should not appear within the figure file, but should be provided in the manuscript text (see Figure Legends).

If a key to an illustration requires artwork (screen lines, dots, unusual symbols), the key should be incorporated into the drawing instead of included in the typed legend. All symbols should be done professionally, be visible against the background, and be of legible proportion should the illustration be reduced for publication.

All microscopic photographs must have a measurement bar and unit of measurement on the image.

\section{Color Figures}

Generally, a maximum of 8 figures will be accepted for clinical report and dental technique articles, and 2 figures will be accepted for tips from our reader articles. However, the Editor may approve the publication of additional figures if they contribute significantly to the manuscript.

Clinical figures should be color balanced. Color images should be in CMYK (Cyan/Magenta/Yellow/ Black) color format as opposed to RGB (Red/Green/Blue) color format.

\section{Graphs/Screen Captures}

Graphs should be numbered as figures, and the fill for bar graphs should be distinctive and solid; no shading or patterns. Thick, solid lines should be used and bold, solid lettering. Arial font is preferred. Place lettering on white background is preferred to reverse type (white lettering on a dark background). Line drawing should be a minimum of $600 \mathrm{dpi}$. Screen Captures should be a minimum of $300 \mathrm{dpi}$ and as close to 5.75 and 3.85 as possible.

\section{Composites}

Composites are multiple images within one Figure file and, as a rule, are not accepted. They will be sent back to the author to replace them with each image sent separately as, Fig. 1A, Fig. 1B, Fig. 1C, etc. Each figure part must meet JPD Guidelines. (Some composite figures are more effective when submitted as one file. These files will be reviewed per case.) Contact the editorial office for more information about specific composites.

\section{Figure Legends}

The figure legends should appear within the text of the manuscript on a separate page after Tables and should appear under the heading FIGURES. Journal style requires that the articles ( $a$, an, and the) are omitted from the figure legends. If an illustration is taken from previously published material, the legend must give full credit to the source (see Permissions).

\section{File Naming}

Each figure file must be numbered according to its position in the text (Figure 1, Figure 2, and so on) with Arabic numerals. The electronic image files must be named so that the figure number and format can be easily identified. For example, a Figure 1 in TIFF format should be named fig. 1.tif. Multipart figures must be clearly identifiable by the file names: Fig. 1A, Fig. 1B, Fig. 1C, Fig. 1-unlabeled, Fig. 1-labeled, etc.

\section{Callouts}


In the article, clearly reference each Figure and Table by including its number in parentheses at the end of the appropriate sentence before closing punctuation. For example: The sutures were removed after 3 weeks (Fig. 4). Or: are illustrated in Table 4.

The Journal reserves the right to standardize the format of graphs and tables.

Authors are obligated to disclose whether illustrations have been modified in any way.

\section{Thumbnails}

Place thumbnails (reduced size versions) of your figures in Figures section below each appropriate legend.

Thumbnails refers to placing a small (compressed file) copy of your figure into the FIGURES section of the manuscript after each appropriate legend. No smaller than $2^{\prime \prime} \times 1.5^{\prime \prime}$ and approximately $72 \mathrm{dpi}$. The goal is to give the editors/reviewers something to review but we want to keep the dimensions and the file size small for easy access. These small images are called thumbnails.

\section{Figures Quick Checklist}

All files are saved as TIFFs or JPEGs (only).Figure size: $5.75^{\prime \prime} \times 3.85^{\prime \prime}$ (radiographs, SEMS, and screen captures may vary but they must all be size-matched). Figures are $300 \mathrm{dpi}$; line or combo line/photo illustrations are minimum $600 \mathrm{dpi}$.For text in figures use Ariel font.Label the Figure files according to their sequence in the text.Provide figure legends in the manuscript Figure section.Place thumbnails (small versions of figure files approx. $2^{\prime \prime} \times 1.5^{\prime \prime}$ ) in Figure section below each legend.Submit composite figure parts as separate files.

A detailed guide to electronic artwork is available on our website: You are urged to visit this site; some excerpts from the detailed information about figure preparation are given here. http://www.elsevier.com/artworkinstructions.

Please make sure that artwork files are TIFFs and with the correct resolution. If, together with your accepted article, you submit usable color figures then Elsevier will ensure, at no additional charge, that these figures will appear in color online (e.g., ScienceDirect and other sites) in addition to color reproduction in print. For further information on the preparation of electronic artwork, please see http://www.elsevier.com/artworkinstructions.

\section{Illustration services}

Elsevier's WebShop (http://webshop.elsevier.com/illustrationservices) offers Illustration Services to authors preparing to submit a manuscript but concerned about the quality of the images accompanying their article. Elsevier's expert illustrators can produce scientific, technical, and medicalstyle images, as well as a full range of charts, tables, and graphs. Image 'polishing' is also available, where our illustrators take your image(s) and improve them to a professional standard. Please visit the website to find out more.

\section{Electronic Artwork}

General points

- Make sure you use uniform lettering and sizing.

- Embed the used fonts if the application provides that option.

- Use the font Ariel or Helvetica in your illustrations.

- Number the illustration files according to their sequence in the text.

- Use a logical naming convention for your artwork files.

- Provide figure legends in the Figure section.

- Size the illustrations close to the desired dimensions of the published version.

- Submit each illustration as a separate file.

A detailed guide on electronic artwork is available on our website:

http://www.elsevier.com/artworkinstructions.You are urged to visit this site; some excerpts from the detailed information are given here.

Formats

If your electronic artwork is created in a Microsoft Office application (Word, PowerPoint, Excel) then please supply 'as is' in the native document format.

Regardless of the application used other than Microsoft Office, when your electronic artwork is finalized, please 'Save as' or convert the images to one of the following formats (note the resolution requirements for line drawings, halftones, and line/halftone combinations given below):

TIFF (or JPEG): Color or grayscale photographs (halftones), keep to a minimum of $300 \mathrm{dpi}$.

TIFF (or JPEG): Bitmapped (pure black \& white pixels) line drawings, keep to a minimum of $600 \mathrm{dpi}$. TIFF (or JPEG): Combinations bitmapped line/half-tone (color or grayscale), keep to a minimum of 600 dpi.

Please do not: 
- Supply files that are optimized for screen use (e.g., GIF, PNG, PICT, WPG); these typically have a low number of pixels and limited set of colors;

- Supply files that are too low in resolution? or smaller than $5.75 \times 3.85$-inch.;

- Submit graphics that are disproportionately large for the content.

Color artwork

Please make sure that artwork files are in an acceptable format (TIFF or JPEG)and with the correct size and resolution. If, together with your accepted article, you submit usable color figures then Elsevier will ensure, at no additional charge, that these figures will appear in color online (e.g., ScienceDirect and other sites) in addition to color reproduction in print. For further information on the preparation of electronic artwork, please see http://www.elsevier.com/artworkinstructions.

\section{Illustration services}

Elsevier's WebShop offers Illustration Services to authors preparing to submit a manuscript but concerned about the quality of the images accompanying their article. Elsevier's expert illustrators can produce scientific, technical and medical-style images, as well as a full range of charts, tables and graphs. Image 'polishing' is also available, where our illustrators take your image(s) and improve them to a professional standard. Please visit the website to find out more.

\section{Figure captions}

Ensure that each illustration has a caption. Supply captions separately, not attached to the figure. A caption should comprise a brief title (not on the figure itself) and a description of the illustration. Keep text in the illustrations themselves to a minimum but explain all symbols and abbreviations used. See Sample Figures page.

\section{Tables}

Tables should be self-explanatory and should supplement, not duplicate the text. Provide all tables at the end of the manuscript after the reference list and before the Figures. There should be only one table per page. Omit internal horizontal and vertical rules (lines). Omit any shading or color.Do not list tables in parts (Table Ia, Ib, etc.). Each should have its own number. Number the tables in the order in which they are mentioned in the text (Table 1., Table 2, etc).Supply a concise legend that describes the content of the table. Create descriptive column and row headings. Within columns, align data such that decimal points may be traced in a straight line. Use decimal points (periods), not commas, to mark places past the integer (eg, 3.5 rather than 3,5). In a line beneath the table, define any abbreviations used in the table.If a table (or any data within it) was published previously, give full credit to the original source in a footnote to the table. If necessary, obtain permission to reprint from

the author/publisher. The tables should be submitted in Microsoft Word. If a table has been prepared in Excel, it should be imported into the manuscript.

\section{References \\ Citation in text}

Please ensure that every reference cited in the text is also present in the reference list (and vice versa). Any references cited in the abstract must be given in full. Unpublished results and personal communications are not permitted in the reference list, but may be mentioned in the text. Citation of a reference as 'in press' implies that the item has been accepted for publication.

\section{Reference links}

Increased discoverability of research and high quality peer review are ensured by online links to the sources cited. In order to allow us to create links to abstracting and indexing services, such as Scopus, CrossRef and PubMed, please ensure that data provided in the references are correct. Please note that incorrect surnames, journal/book titles, publication year and pagination may prevent link creation. When copying references, please be careful as they may already contain errors. Use of the DOI is encouraged.

A DOI can be used to cite and link to electronic articles where an article is in-press and full citation details are not yet known, but the article is available online. A DOI is guaranteed never to change, so you can use it as a permanent link to any electronic article. An example of a citation using DOI for an article not yet in an issue is: VanDecar J.C., Russo R.M., James D.E., Ambeh W.B., Franke M. (2003). Aseismic continuation of the Lesser Antilles slab beneath northeastern Venezuela. Journal of Geophysical Research, http://dx.doi.org/10.1029/2001JB000884i. Please note the format of such citations should be in the same style as all other references in the paper. 
Acceptable references and their placement

Most, if not all, references should first be cited in the Introduction and/or Material and Methods section. Only those references that have been previously cited or that relate directly to the outcomes of the present study may be cited in the Discussion.

Only peer-reviewed, published material may be cited as a reference. Manuscripts in preparation, manuscripts submitted for consideration, and unpublished theses are not acceptable references.

Abstracts are considered unpublished observations and are not allowed as references unless followup studies were completed and published in peer-reviewed journals.

References to foreign language publications should be kept to a minimum (no more than 3 ). They are permitted only when the original article has been translated into English. The translated title should be cited and the original language noted in brackets at the end of the citation.

Textbook references should be kept to a minimum, as textbooks often reflect the opinions of their authors and/or editors. The most recent editions of textbooks should be used. Evidence-based journal citations are preferred.

Reference formatting

References must be identified in the body of the article with superscript Arabic numerals. At the end of a sentence, the reference number falls after the period.

The complete reference list, double-spaced and in numerical order, should follow the Conclusions section but start on a separate page. Only references cited in the text should appear in the reference list.

Reference formatting should conform to Vancouver style as set forth in "Uniform Requirements for Manuscripts Submitted to Biomedical Journals" (Ann Intern Med 1997;126:36-47).

References should be manually numbered.

List up to six authors. If there are seven or more, after the sixth author's name, add et al.

Abbreviate journal names per the Cumulative Index Medicus. A complete list of standard abbreviations is available through the PubMed website: http://www.ncbi.nlm,nih.gov/nlmcatalog/journals.

Format for journal articles: Supply the last names and initials of all authors; the title of the article; the journal name; and the year, volume, and page numbers of publication. Do not use italics, bold, or underlining for any part of the reference. Put a period after the initials of the last author, after the article title, and at the end of the reference. Put a semicolon after the year of publication and a colon after the volume. Issue numbers are not used in Vancouver style.

Ex: Jones ER, Smith IM, Doe JQ. Uses of acrylic resin. J Prosthet Dent 1985;53:120-9.

Book References: The most current edition must be cited. Supply the names and initials of all authors/ editors, the title of the book, the city of publication, the publisher, the year of publication, and the inclusive page numbers consulted. Do not use italics, bold, or underlining for any part of the reference.

Ex: Zarb GA, Carlsson GE, Bolender CL. Boucher's prosthodontic treatment for edentulous patients. 11 th ed. St. Louis: Mosby; 1997. p. 112-23.

References should not be submitted in Endnote or other reference-generating software. Endnote formatting cannot be edited by the Editorial Office or reviewers, and must be suppressed or removed from the manuscript prior to submission. Nor should references be automatically numbered. Please number manually.

See Sample Manuscript. 